\title{
PROMOTING "ACADEMIC ENTREPRENEURSHIP” IN EUROPE AND THE UNITED STATES: CREATING AN INTELLECTUAL PROPERTY REGIME TO FACILITATE THE EFFICIENT TRANSFER OF KNOWLEDGE FROM THE LAB TO THE PATIENT
}

\author{
CONSTANCE E. BAGLEY* \& CHRISTINA D. TVARnØ**
}

In 2014, the European Commission announced the launch of a study of knowledge transfer by public research organizations and other institutes of higher learning "to determine which additional measures might be needed to ensure an optimal flow of knowledge between the public research organisations and business thereby contributing to the development of the knowledge based economy." As the European Commission has recognized, the European Union ("EU") needs to take action to "unlock the potential of IPRs [intellectual property rights] that lie dormant in universities, research institutes and companies." This article builds on our earlier work on structuring efficient pharmaceutical public-private partnerships ("PPPPs"), but focuses on the regulatory infrastructure necessary to support the efficient commercialization of publicly funded university medical research in both the European Union and the United States ("U.S."). Our comparative analysis of the EU and U.S. approaches to translational medicine shows that there are lessons to be shared. The EU can apply the experiences from the U.S. Bayh-Dole Act and PPPPs in the United States, and the United States can emulate certain of the open innovation aspects of the European Innovative Medicines Initiative and the tighter patenting standards imposed by the European Patent Office. Thus, a secondary purpose of this article is suggesting amendments to the U.S. laws governing the patenting and licensing of government-funded

\footnotetext{
Copyright (C) 2015 Constance E. Bagley and Christina D. Tvarnø

* Constance E. Bagley is a Senior Research Scholar at the Yale Law School and was previously Professor in the Practice of Law and Management at Yale University, Associate Professor of Business Administration at the Harvard Business School, and a partner of Bingham McCutchen LLP. Both authors thank Susan Schillaci for her excellent research assistance.

** Christina D. Tvarnø is Professor, Ph.D. in Public-Private Law, the Law Department, Copenhagen Business School.
} 
technology to prevent undue burdens on the sharing of certain upstream medical discoveries and research tools.

\section{TABLE OF CONTENTS}

INTRODUCTION

I. THE GLOBAL PHARMACEUTICAL SUPPLY CHAIN ….............................. 10

II. THE EU INNOVATIVE MEDICINES INITIATIVE AND THE ACTION

PLAN AGAINST THE RISING THREATS FROM

ANTIMICROBIAL RESISTANCE

A. Goals and Structure of the Innovative Medicines Initiative ................ 16

B. Ownership of IMI-Funded Inventions............................................ 18

C. Action Plan Against the Rising Threats from Antimicrobial

Resistance.

III. THE U.S. NATIONAL CENTER FOR ADVANCING

TRANSLATIONAL SCIENCES AND OTHER U.S. PROGRAMS ......... 19

IV. UNIVERSITY TECHNOLOGY TRANSFER ….........................................2 20

A. Laws Regulating Technology Transfer in the United States ...............22

1. The Bayh-Dole Act .................................................................. 23

2. Employers' Rights to Inventions Created by Employees Hired to Invent and Contractual Assignments of Inventions ..................25

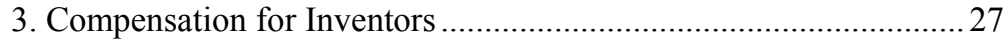

4. University Technology Transfer Offices........................................ 29

B. Laws Regulating Technology Transfer in the European Union ........... 31

1. Allocation of Ownership Rights Between the University and

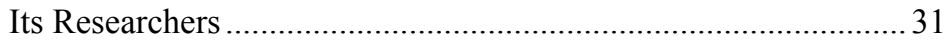

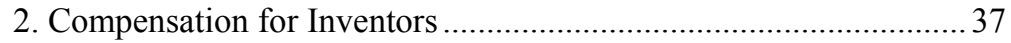

3. University Technology Transfer Offices....................................... 38

4. Recent Changes to the EU Patenting Regime ................................ 41

C. Comparative Data on Academic Patenting in the United States and Europe

V. PUBLIC POLICY CONCERNS RAISED BY UNIVERSITY

LICENSING IN THE UNITED STATES AND THE EUROPEAN

UNION

VI. CREATING A NEW TECHNOLOGY TRANSFER MODEL FOR THE EUROPEAN UNION

A. Ensuring a Clear and Efficient Allocation of Intellectual Property

Rights

1. Harmonization with Flexibility ...

2. Understanding the Differing Utility Functions of Three Dyads in the EU.

a. The EU and the Member State ................................................. 55

b. The Member State and the University or Industrial Firm ..........57

c. The University and Its Industrial Partner and the Research

Scientists 
B. Navigating the "Anticommons"

1. Create a Broad Experimental Use Exemption................................. 64

2. Establish a Compulsory Licensing Regime and Provide a Safe

Harbor for Patent Pools

3. Require More Complete Enabling Descriptions.............................. 67

4. Promote Open Innovation Collaborations ….................................... 68

5. Other Recommended Changes to the Bayh-Dole Regime .............. 69

C. Complying with the EU State Aid Restrictions............................... 70

CONCLUSION.

"[P]atent protection strikes a delicate balance between creating 'incentives that lead to creation, invention, and discovery' and 'imped[ing] the flow of information that might permit, indeed spur, invention. ","1

\section{INTRODUCTION}

To improve industry competitiveness ${ }^{2}$ and address unmet health needs, government agencies in both the European Union ("EU") and the United States ("U.S.") are working with public universities and for-profit pharmaceutical firms "to foster translation [of medical discoveries] from the university to the healthcare sector through the generation and support of start-ups, spin-offs, university-industry consortia, and other platforms[.]",3 The goal: facilitating the movement of discoveries from "bench to bedside." 4

One example is the Precision Medicine Initiative ("PMI"), a \$215 million public-private project announced by President Obama in 2015, which presents "one of the greatest opportunities for new medical breakthroughs that we have ever seen." Under the PMI, research

1. Ass'n for Molecular Pathology v. Myriad Genetics, Inc., 133 S. Ct. 2107, 2116 (2013) (emphasis added) (quoting Mayo Collaborative Servs. v. Prometheus Labs., Inc., 132 S. Ct. 1289, 1305 (2012)).

2. As EU Internal Market and Services Commissioner Michel Barnier put it: "It is my deeply held conviction there is no sustainable economic growth without innovation. And no innovation without efficient intellectual property protection[.]" Press Release, European Comm'n, European Patents Costs to Be Radically Reduced (Apr. 13, 2011), ec.europa.eu/unitedkingdom/press/press_releases/.../ pr1138_en.htm.

3. Rogério Gaspar et al., Towards a European Strategy for Medicines Research (2014-2020): The EUFEPS Position Paper on Horizon 2020, 47 EUR. J. PhARMA. ScIS. 979, 980 (2012).

4. Id.

5. President Barack Obama, Remarks by the President on Precision Medicine (Jan. 30, 2015), http://www.whitehouse.gov/the-press-office/2015/01/30/remarks-president-precision-medicine; Robert Pear, U.S. to Collect Genetic Data to Hone Care, N.Y. TimES, Jan. 31, 2015, at A12; Meg Tirrell \& Cara Caruso, Obama Seeks \$215 Million for Precision Medicine, CNBC (Jan. 30, 2015), www.cnbc.com/id/102382752. 
universities, for-profit pharmaceutical firms, and others will collaborate to collect genetic, health, and environmental information from one million Americans in an effort to promote treatments tailored to individual patients. ${ }^{6}$ Britain launched a similar initiative- the Precision Medicine Catapult - in 2015. ${ }^{7}$

In 2014, the European Commission launched a study of knowledge transfer by public research organizations and other institutions of higher learning 8 "to determine which additional measures might be needed to ensure an optimal flow of knowledge between the public research organisations and business thereby contributing to the development of the knowledge based economy." The study was designed to help implement Horizon 2020, a $€ 80$ billion program for research and innovation approved by the European Parliament and Council in December $2013 .{ }^{10}$ Regulators in the EU have already identified public-private and public-public partnerships as "key elements" of the "Innovation Union," a feature of Horizon 2010. ${ }^{11}$ Slated to run from 2014 to 2020, the Innovation Union "aims to improve conditions and access to finance for research and innovation, to ensure that innovative ideas can be turned into products and services that create growth and jobs."12

But notwithstanding such initiatives to promote "academic entrepreneurship," "13 most university technology transfer offices are not

6. Pear, supra note 5; Tirrell \& Caruso, supra note 5.

7. Kate Sweeney, Cambridge to Host Precision Medicine Catapult Network, BuS. WKLY. (July 13, 2015), http://www.businessweekly.co.uk/news/biomedtech/cambridge-host-precision-medicinecatapult-network.

8. European Commission - State of the Innovation Union: Taking Stock 2010 - 2014, at 57, COM (2014) 339 [hereinafter EC Taking Stock 2014].

9. Id.

10. The European Commission described Horizon 2020 as "the biggest EU research and innovation framework programme ever launched, with over $€ 80$ billion dedicated to excellent research, industrial leadership and key societal challenges. It contributes to strengthening the knowledge base in Europe not only by funding research, but also by mainstreaming funding for activities in all stages of the innovation cycle, from frontier research to close-to-market innovation. It supports and encourages the participation of businesses, including SMEs [small and medium-sized enterprises]. In parallel, billions are being invested in innovation-driven public private partnerships." Id. at 12 .

11. An Investment Plan for Europe, COM (2014) 903 final (Nov. 26, 2014).

12. Communication from the Commission to the European Parliament, the Council, the European Economic and Social Committee and the Committee of the Regions, Europe 2020 Flagship Initiative, Innovation Union, at 6, COM (2010) 546 final (Oct. 6, 2010) [hereinafter Europe 2020 Flagship Initiative].

13. Rosa Grimaldi et al., 30 Years After Bayh-Dole: Reassessing Academic Entrepreneurship, 40 RES POL'y 1045, 1045 (2011) (defining "academic entrepreneurship" as the "commercialization of innovations developed by academic scientists" through "patenting, licensing, start-up creation, and university-industry partnerships"). 
profitable; the few that are generate an income stream that "is still a relatively small percentage of the total research volume."14 For example, of the 734 licensing deals entered into by the University of California system between 1981 and 1999, only 188 resulted in positive royalty payments. ${ }^{15}$ Similarly, between 1980 and 2004, only 358 of 2,270 inventions developed at the Max Planck Society ${ }^{16}$ yielded positive royalty income. ${ }^{17}$ In 2007, total licensing income represented just one percent of the Max Planck Society's annual budget. ${ }^{18}$ The European Commission recognized the problem these statistics illustrate, stating: "We need to get more innovation out of our research. Cooperation between the worlds of science and the world of business must be enhanced, obstacles removed and incentives put in place." ${ }^{19}$ Yet, as Guido Buenstorf and Matthias Geissler explain:

Commercializing academic inventions is non-trivial because they are often far from being readily marketable. Prior work suggests that commercialization is complicated by uncertainty stemming from the early-stage character of most university inventions, information asymmetry between inventor and potential licensee, and also the noncodified nature of important elements of the knowledge base underlying the traded technology. ${ }^{20}$

For example, although researchers at universities have worked with for-profit pharmaceutical firms to commercialize discoveries flowing from the successful mapping of the human genome, ${ }^{21}$ barriers to commercialization remain. Extensive research in expensive facilities is

14. Hester Tak \& Bob Smailes, UniLink: A New Model for Increasing Academic and Industry Partnerships, 49 LES NOUVELLES 215, 218 (2014).

15. Robert A. Lowe \& Arvids A. Ziedonis, Overoptimism and the Performance of Entrepreneurial Firms, 52 MGMT. SCI. 173, 177 (2006).

16. The Max Planck Society is "Germany's largest non-university public research organization ... dedicated to basic science." Guido Buenstorf \& Matthias Geissler, Not Invented Here: Technology Licensing, Knowledge Transfer and Innovation Based on Public Research, $22 \mathrm{~J}$. EVOLUTIONARY ECON. 481, 482 (2012).

17. Id. at 496.

18. Id. at 495 .

19. Europe 2020 Flagship Initiative, supra note 12, at 3.

20. Buenstorf \& Geissler, supra note 16 , at 482.

21. Robert I. Field, How the Government Created and Sustains the Private Pharmaceutical Industry, 6 ST. Louis U. J. HeAlTH L. \& POL'Y 11, 28 (2012). The U.S. Government spent \$3.8 billion mapping the complete set of human genes. $I d$. at 30 . To encourage private scientists to participate in the project, the government put its findings in a public database within twenty-four hours of discovery, with no limitations on their use. Id. at 28. 
required to convert the findings of pharmacogeneticists ${ }^{22}$ into a treatment regime. A pharmaceutical company may spend an estimated $\$ 5$ billion bringing a new drug to market, a figure that includes the cost of unsuccessful drug candidates. ${ }^{23}$ While pharmacogenomic products offer "personalized medicine," a benefit to the patient receiving the drug, pharmaceutical companies lack incentive to develop pharmacogenomic products because of (1) small sample sizes in clinical trials, which can increase the cost of the already expensive new drug approval process by requiring extra trials and research; ${ }^{24}$ (2) lack of coverage by Medicare and private insurers for the companion genetic tests; ${ }^{25}$ and (3) concern about limiting the pool of people who will receive their drug. ${ }^{26}$

Another costly area is microbiotics, the study of the microbial cells in the human body. Microbial cells outnumber human cells roughly ten to one and are thought to interact with the human host to support health or trigger disease. $^{27}$ Scientists are now applying many of the tools developed for pharmacogenetics to study the human microbiome, the genes of the several

22. Pharmacogenetics is the study of genetic traits that "might underlie variation among individuals in drug response, based on individual differences in enzyme structure and function." Valerie Gutmann Koch, Incentivizing the Utilization of Pharmacogenomics in Drug Development, 15 J. HEALTH CARE L. \& POL'Y 263, 264 (2012). Its focus is the reaction of genetically diverse patients to a specific, often preexisting, medication: "one drug across many genomes." $I d$. at 265 . As such, it is at the drug discovery stage where pharmacogenomics "exert[s] its impact"; this impact will be present in products "over the long term." Id. Only 1 out of 60,000 compounds created by drug companies are highly successful; roughly 1 out of 6 drugs put into clinical trials are ultimately approved by the U.S. Food and Drug Administration (FDA); and more than $3 \%$ of drugs approved by the FDA were subsequently withdrawn between 1971 and 2006 due to negative side effects. Id. at $274 \mathrm{n} .89,276$. Pharmacogenomics includes not only pharmacogenetics but also research conducted during the earlier stages in a drug's development to determine "which compounds will be most effective for a particular genome ('many drugs across one genome')." Id. at 264.

23. David C. Babaian, Adopting Pharmacogenomics and Parenting Repurposed Molecules Under the Orphan Drug Act: A Cost Dilemma, 13 J. Marshall ReV. InTELl. Prop. L. 667, 673-74 (2014). Small biotech firms have entered into agreements with large pharmaceutical firms to develop pharmacogenetic test kits and innovations. Koch, supra note 22 , at 279 . They include a $\$ 200$ million agreement between Roche and deCODE Genetics "to identify disease genes through genetic analysis of the uniquely homogenous Icelandic population." Id. at 280 (quoting Allen C. Nunnally et al., Intellectual Property and Commercial Aspects of Pharmacogenomics, in PHARmacogenomics: SOCIAL, ETHICAL, AND CLINICAL DimENSIONS 109, 127-28 (Mark A. Rothstein ed., 2003)).

24. Sarah Blankstein, Pharmacogenomics: History, Barriers, and Regulatory Solutions, 69 FOOD \& DRUG L.J. 273, 273-75 (2014).

25. Id. at 275 .

26. Id.

27. Michael Pollan, Some of My Best Friends Are Germs, N.Y. Times MAG., May 15, 2013, at MM36. A healthy human has more than 100 trillion bacteria. Id. The collective genome of a microbial community "is estimated to be 100- to 1000-fold that of human cells, which comprise 23,000 genes." Linda C. Duffy et al., Progress and Challenges in Developing Metabolic Footprints from Diet in Human Gut Microbial Cometabolism, J. NuTRITION, Apr. 1, 2015, 1S, 1S, http://jn.nutrition.org/ content/early/2015/04/01/jn.114.194936. 
hundred microbial species in the human body. ${ }^{28}$ Many scientists believe that this "second genome" can affect one's health more than one's inherited genes, and that it may be possible to "reshape" or "cultivate" microbiota. ${ }^{29}$ Developments in metagenomics have already made it possible to examine the ways the microbiome and human host interact without having to cultivate bacterial strains in the laboratory. ${ }^{30}$

Microbiotics offers possible treatments for certain autoimmune diseases and other ailments. ${ }^{31}$ Scientist Jeff Gordon predicts that disorders of the microbiome will eventually be treated with "synbiotics," nextgeneration probiotic microbes that patients will take with prebiotic nutrients, as well as with new "therapeutic foods" that will heal various intestinal issues. ${ }^{32}$ Both Big Pharma and Big Food will likely have a large stake in "repairing the microbiota of people who can't or don't care to simply change their diets." 33 Because of their extensive research requirements, macrobiotics and metagenomics as well as pharmacogenetics are important areas for public-private cooperation.

To promote research in this area, the U.S. National Institutes of Health ("NIH") created the five-year Common Fund Human Microbiome Project ("HMP") in 2007, allocating $\$ 217$ million to fund research on human microbiota and to develop "metagenomics datasets and computational tools for characterizing the microbiome in healthy adults and in cohorts of specific microbiome-associated diseases." 34 A second phase of HMP began in 2013, was funded with $\$ 15$ million from the NIH Common Fund, and will focus on the microbiome and its role in pregnancy and birth, diabetes,

28. Pollan, supra note 27. The term "microbiota" refers to all the microbes in a community, and the term "microbiome" refers to their collective genes. Id.

29. Id.

30. The NIH explained: "Advances in DNA sequencing technologies have created a new field of research, called metagenomics, allowing comprehensive examination of microbial communities without the need for cultivation [in a laboratory]. Instead of examining the genomes of individual bacterial strains that have been grown in the laboratory and then trying to reassemble the community of microbes, the metagenomic approach allows analysis of genetic material harvested directly from microbial communities without the need to culture the microbes. In the HMP, this approach is complementing genetic analyses of available reference strains, providing unprecedented information about the complexity of human-associated microbial communities. Other advanced 'omics technologies like transcriptomics, proteomics and metabolomics, which measure the biological properties of whole microbial communities, are being used to provide insights into how the microbiome and human host interact to support health or to trigger disease." Human Microbiome Project: Overview, NAT'L INST. OF HEALTH, http://commonfund.nih.gov/hmp/overview (last updated Sept. 24, 2014).

31. Pollan, supra note 27.

32. Id.

33. Id.

34. Human Microbiome Project: Overview, supra note 30. 
and inflammatory bowel disease. ${ }^{35}$ Another endeavor, the American Gut Project, is an open-source project involving researchers across the globe that seeks the participation of tens of thousands of "citizen scientists" to provide specimens for study. ${ }^{36}$ The project hopes to sequence the microbiome of the participants and to "uncover patterns of correlation between people's lifestyle, diet, health status and the makeup of their microbial community.",37

Patents and exclusive licenses of patented technology are the primary legal tools used to recoup a firm's investment in the commercialization of a new pharmaceutical compound, biologic, synbiotic, or genetically engineered therapeutic food. ${ }^{38}$ Although patents spur investment, they also

35. Id.; Steven Benowitz, Human Microbiome Meeting Highlights Research Progress in a Field Already Beginning to Matter, NAT'L HuMAN GENOME RESEARCH InST., https:/www.genome.gov/ 27554771 (last updated Aug. 20, 2014). In 2014, the NIH invited applications for a \$1 million grant designed to study gut-microbiome-brain interactions. Part 1. Overview Information, DEP'T OF HEALTH \& HUMAN SERVS., http:/grants.nih.gov/grants/guide/rfa-files/RFA-MH-15-850.html (last visited Sept. 1, 2015).

36. American Gut, SCI. AM., http://www.scientificamerican.com/citizen-science/american-gut/ (last visited Nov. 18, 2014). The American Gut Project initially raised roughly $\$ 350,000$ through the crowd-sourcing portal Indiegogo. Jessica Marshall, Kickstart Your Research, 110 PNAS 4857, 485759, http://www.pnas.org/content/110/13/4857.full.

37. American Gut, supra note 36.

38. See generally Bowman v. Monsanto Co., 133 S. Ct. 1761 (2013) (holding that a farmer may not reproduce genetically modified soybean seeds patented by Monsanto by replanting and then harvesting more seeds than he had originally purchased without the permission of the patent holder). Pharmaceutical companies must be wary of "product hopping" when promoting new versions of existing drugs that are reaching the end of their patent life, as it may be considered unlawful monopolization triggering antitrust enforcement. Second Circuit Rules that "Product Hopping" May Constitute Unlawful Monopolization; Pharmaceutical Companies are Likely Targets of Future Antitrust Enforcement, COOLEY LLP (June 12, 2015), http://www.cooley.com/71569?MailKey=9374288. In New York v. Actavis PLC, the U.S. Court of Appeals for the Second Circuit examined "a novel question of antitrust law: under what circumstances does conduct by a monopolist to perpetuate patent exclusivity through successive products, commonly known as 'product hopping,' violate the Sherman Act." 787 F.3d 638, 643 (2d Cir. 2015). New York State had alleged that as the patent exclusivity period neared for Actavis' twice-daily Alzheimer's drug Namenda IR, Actavis introduced a new, once-daily version of the drug called Namenda XR. The patents on XR ensured exclusivity and prohibited generic versions until 2029. Because of potential competition from the forthcoming generic version of IR, Actavis withdrew "virtually all" IR from the market, forcing Alzheimer's patients who used IR to switch to XR before the generic versions of IR became available. New York alleged that such a "forced-switch scheme" would likely impede generic competition for IR, and that the high costs of switching from the once-daily XR back to twice-daily IR use would likely further ensure that Actavis maintained its effective monopoly in the relevant drug market beyond the time granted by the IR patents. The Second Circuit held that withdrawing the twice-daily version was a violation of the Sherman Act, affirming the district court's grant of a preliminary injunction that barred Actavis from restricting access to the twicedaily IR version and from charging more for it than when XR was first introduced. $I d$. at 663 . This is just one example of what can be the complex interplay between the legitimate use of the exclusivity provided by patents and the unlawful monopolization prohibited by the antitrust laws. 
reduce competition, leading to higher prices. ${ }^{39}$ And they can impede further innovation. As the U.S. Supreme Court stated in Association for Molecular Pathology v. Myriad Genetics, Inc.: “[P]atent protection strikes a delicate balance between creating 'incentives that lead to creation, invention, and discovery' and 'imped[ing] the flow of information that might permit, indeed spur, invention." "40 These are not only hotly contested contractual issues, ${ }^{41}$ but matters of social and governmental import. Accordingly, "[p]olicy-makers must... determine, through the patent system, how to balance the promotion of downstream pharmacogenomic [and other pharmaceutical] research while protecting the rights of innovators." ${ }^{2}$

The purpose of this article is to advance the public policy and academic debate in both the EU and the United States concerning the intellectual property issues inherent in drug development collaboration among government, academia, and private industry-what has been dubbed the "triple helix." 43 We propose solutions that build on aspects of both the European Innovation in Medicines Initiative ("IMI") and the Bayh-Dole Act, ${ }^{44}$ the U.S. statute governing the patenting and licensing of government-funded university technology. We also extend the game theory analysis of public-private partnerships we presented in an earlier article ${ }^{45}$ to include the incentives necessary to persuade academic researchers to share their tacit knowledge with the commercial partner in a PPPP.

Part I briefly describes global trends in pharmaceutical research, development, and commercialization before outlining the role pharmaceutical public-private partnerships can play in this process. Parts II and III

39. For example, Myriad Genetics was able to charge $\$ 3,000$ for a test for the two breast cancer genes BRCA1 and BRCA2 because it had patents on those gene sequences, while a university lab can sequence 20,000 genes for less than \$500. Although the U.S. Supreme Court invalidated Myriad's patent on isolated gene sequences because they are naturally occurring substances, it upheld the patent on cDNA, the synthetic complementary DNA used to develop tests for specific genetic markers. Ass'n for Molecular Pathology v. Myriad Genetics, Inc., 133 S. Ct. 2107, 2119 (2013).

40. Id. at 2116 (quoting Mayo Collaborative Servs. v. Prometheus Labs., Inc., 132 S. Ct. 1289, 1305 (2012)).

41. See, e.g., Suzanne Majewski \& Dean V. Williamson, Incomplete Contracting and the Structure of R\&D Joint Venture Contracts, in INTELLECTUAL PROPERTY AND ENTREPRENEURSHIP 201 (Gary D. Libecap ed., 2004) (stressing importance of allocating property rights in R\&D ventures ex ante by contract).

42. Koch, supra note 22, at 302.

43. See generally Loet Leydesdorff, The Triple Helix: An Evolutionary Model of Innovations, 29 RES. POL'y 243 (2000) (explaining that universities can play as critical a role as government and industry in knowledge-based societies).

44. Bayh-Dole Act, Pub. L. No. 96-517, 94 Stat. 3015 (1980) (codified as amended at 35 U.S.C. $\S \S 200-212(2012))$.

45. See generally Constance E. Bagley \& Christina D. Tvarnø, Pharmaceutical Public-Private Partnerships: Moving from the Bench to the Bedside, 4 HARV. BUS. L. REV. 373 (2014). 
discuss the EU IMI and three U.S. NIH translational medicine initiatives. Part IV discusses technology transfer from academia to industry, including the ownership of inventions, licensing and patent considerations, the role of university technology transfer offices, and recent changes to the EU patent regime. Part $\mathrm{V}$ presents public policy concerns raised by university licensing to private firms. Finally, Part VI concludes by proposing an intellectual property regime for the EU designed to promote the commercialization of technology developed in university laboratories with government funds without jeopardizing either the historic role of universities in Europe or the goals of the common market reflected in the restrictions on state aid.

\section{THE GLOBAL PHARMACEUTICAL SUPPLY CHAIN}

The existing productivity challenge in the pharmaceutical industry is a result of increasing research and development ("R\&D") costs, decreasing production, a lack of administrative approval of new products, reduced public funding, and empty or exhausted pipelines. ${ }^{46}$ In 2012, the "year of all patent-cliff years," the patents on AstraZeneca's Seroquel IR, BristolMyers Squibb's Plavix, and Merck's Singulair all expired. ${ }^{47}$ Pfizer's patent on Lipitor had expired in late $2011 .^{48}$ Table 1 reflects the resulting financial pressure on pharmaceutical companies around the world. ${ }^{49}$

46. See, e.g., Martin Grueber \& Tim Studt, Battelle, 2014 Global R\&D Funding FORECAST 22 (2013), http://www.battelle.org/docs/tpp/2014_global_rd_funding_forecast.pdf (noting that "pressures persist to improve on productivity, product pipelines and ROI in consideration of expiring patents, cost pressures and the rising complexity of innovation in drug development" and that when traditional pharmaceutical companies "struggle with reduced product pipelines and productivity from discovery through development ... R\&D spending often declines"); Sam Stein, Ebola Vaccine Would Likely Have Been Found by Now if Not for Budget Cuts: NIH Director, HuFFINGTON PosT (Oct. 12, 2014), http://www.huffingtonpost.com/2014/10/12/ebola-vaccine_n_5974148.html (Dr. Francis Collins, the director of the National Institutes of Health, explained that the organization had gone through a "10-year slide in research support" and that the institute's "purchasing power is down 23 percent from what it was a decade ago.").

47. Top Pharma Companies by 2012 Revenues, FierCePharma (Mar. 26, 2013), http://www. fiercepharma.com/special-reports/top-pharma-companies-2012-revenues.

48. Id.

49. See generally Tom. R. Denee et al., Measuring the Value of Public-Private Partnerships in the Pharmaceutical Sciences, 11 NATURE REVIEWS DRUG DisCOVERY 419 (2012). 
Table 1: The Top Fifteen Pharmaceutical Companies by 2013 and 2012 Revenues

\begin{tabular}{|l|l|l|l|l|l|}
\hline Company & $\begin{array}{l}\text { Head- } \\
\text { quarters }\end{array}$ & $\begin{array}{l}\mathbf{2 0 1 3} \\
\text { Rank }\end{array}$ & $\begin{array}{l}\mathbf{2 0 1 3} \\
\text { Revenues } \\
\text { (U.S. Sb) }\end{array}$ & $\begin{array}{l}\mathbf{2 0 1 2} \\
\text { Rank }\end{array}$ & $\begin{array}{l}\mathbf{2 0 1 2} \\
\text { Revenues } \\
\text { (U.S. \$b) }\end{array}$ \\
\hline Pfizer & U.S. & 1 & 47.88 & 1 & 51.21 \\
\hline Novartis & EU & 2 & 47.47 & 2 & 46.73 \\
\hline Roche & EU & 3 & 39.16 & 5 & 38.01 \\
\hline Merck \& Co. & U.S. & 4 & 37.44 & 3 & 40.60 \\
\hline Sanofi & EU & 5 & 37.12 & 4 & 39.51 \\
\hline GlaxoSmithKline & EU & 6 & 33.33 & 6 & 33.34 \\
\hline $\begin{array}{l}\text { Johnson \& } \\
\text { Johnson }\end{array}$ & U.S. & 7 & 28.13 & 8 & 25.35 \\
\hline AstraZeneca & U.S. & 8 & 25.71 & 7 & 27.93 \\
\hline Lilly & EU & 9 & 20.96 & 9 & 20.57 \\
\hline AbbVie & U.S. & 10 & 18.79 & 11 & 18.38 \\
\hline Teva & Israel & 11 & 18.31 & 10 & 18.54 \\
\hline Amgen & U.S. & 12 & 18.19 & 14 & 16.64 \\
\hline Takeda & Japan & 13 & 17.41 & 13 & 17.56 \\
\hline $\begin{array}{l}\text { Bristol-Myers } \\
\text { Squibb }\end{array}$ & U.S. & 14 & 16.39 & 12 & 17.62 \\
\hline $\begin{array}{l}\text { Boehringer } \\
\text { Ingelheim }\end{array}$ & U.S. & 15 & 15.79 & 15 & 14.66 \\
\hline
\end{tabular}

Source: Top 25 Pharma Companies by Global Sales, PMLIVE, http:/www.pm live.com/top_pharma_list/global_revenues (last visited Nov. 19, 2014).

Research published in 2015 in the Journal of the American Medical Association found that while "[m]edical research in the United States remains the primary source of new discoveries, drugs, devices, and clinical procedures for the world... the U.S. lead in these categories is declining. ${ }^{.50}$ In 2011, for instance, the United States' share of total medical research spending (both academic and commercial) had decreased to fortyfour percent, while Europe - the second largest sponsor - maintained a thirty-three percent share. ${ }^{51}$ Between 2000 and 2009, the number of biomedical research articles published by U.S. scientists increased by only

50. Hamilton Moses III et al., The Anatomy of Medical Research: US and International Comparisons, 313(2) J. AM. MED. Ass'N 174, 181 (2015).

51. Id. at 179. In 2004, the United States funded fifty-seven percent of global medical research. 
$0.6 \%$ annually. In contrast, the number of articles published by Chinese scientists during that same period increased by more than $18 \%$ annually. ${ }^{52}$

Similarly, while the U.S. share of global government and industry funding for medical research has decreased in recent years, spending has markedly increased in Asia, especially in China, India, Japan, Singapore, and South Korea. ${ }^{53}$ Since 2004, the U.S. share of industry funding has dropped from nearly $50 \%$ to $41 \%,{ }^{54}$ and, during that same period, Japan has increased its share of industry funding by $3.9 \%{ }^{55}$ In 2011 , China filed $30 \%$ of global life sciences patents, up from just $1 \%$ in 1991. But the United States' share grew comparatively slowly, increasing from $11 \%$ to $24 \%$ in that time. ${ }^{56}$ Additionally, between 1991 and 2011, the percentage of "highly valuable patents," measured by subsequent citation counts, decreased for patents issued to U.S. inventors by the U.S. and European patent offices. $^{57}$

Between 2003 and 2013, the European Medicines Agency ("EMA") received on average more drug applications (fifty-five per year) and approved more drugs (forty-two per year) than the U.S. Food and Drug Administration ("FDA"), which averaged twenty-six approvals per year in the same period. ${ }^{58}$ In 2013 alone, the EMA received twenty-two more applications and approved sixteen more drugs than the FDA, suggesting that, at least in terms of number of new drugs approved for use, Europe is continuing to outpace the United States. ${ }^{59}$ A study involving patenting by 492 tenured engineering academics working in the United Kingdom between 1996 and 2007 showed that "UK researchers receiving funding from industry are more likely to produce patents, controlling for a variety of individual and departmental characteristics, ${ }^{, 60}$ than UK researchers not

52. Id. at 181 .

53. Id. at $178-79$.

54. Id. at 179 .

55. Id.

56. Id. at 180

57. Id. China's percentage of highly valuable patents increased between 1991 and 2011. See id. at 184.

58. Id. at 181

59. Id.

60. Cornelia Lawson, Academic Patenting: The Importance of Industry Support, 38 J. TECH. TRANSFER 509, 510 (2013). Even small industry grants, "which may support [knowledge] dissemination activities, studentships and consulting," and indicate close links between the industrial sponsor and the academic researchers, positively affect patenting. Id. at 510, 518. Researchers also found a strong positive correlation between industry collaboration and funding and patenting by Norwegian academics, and a positive correlation between industry sponsorship of German science and engineering departments and patent citations. Id. at 512 (citing M. Gulbrandsen \& J.C. Smeby, Industry Funding and University Professors' Research Performance, 34(6) RESEARCH POL'Y 932 (2005), and H. 
receiving industry funding, suggesting the important role industry can play in academic entrepreneurship.

The reduction in the U.S. government share of spending on medical research may be one reason why private firms have, since 2003, increasingly focused on later-stage clinical trials and product development, reducing their "discovery-level investment" in activities such as target identification and validity. ${ }^{61}$ This shift has widened the "so-called "valley of death," which separates "upstream research on promising genes, proteins, and biological pathways" by government-funded academic researchers from "downstream drug candidates"62 outside firms fund in hopes of commercializing the researchers' discoveries. ${ }^{63}$ This gap is particularly difficult to bridge given not only the cost of commercializing a compound, biologic, or symbiotic, but also the inherent tension between the goals of academia and the commercial sector. Whereas universities (a term we use to include research institutes) focus primarily on the public dissemination of new knowledge and discoveries, the private sector is often more concerned with capturing the revenues available to the patent-holding firm or an exclusive licensee.

As we explain in our article "Pharmaceutical Public-Private Partnerships: Moving from the Bench to the Bedside,"64 a properly structured pharmaceutical public-private partnership ("PPPP") ${ }^{65}$ can help bridge the "valley of death." Used more commonly in the United States than in Europe, a PPPP is an arrangement between a university (whether governmentally or privately funded) and one or more private pharmaceutical firms to develop new medicines that can be sold by the firms for a profit. ${ }^{66}$

Hottenrott \& S. Thorwarth, Industry Funding of University Research and Scientific Productivity, 64(4) KYKLOS 534 (2011)). U.K. academic inventors who had filed a patent application while working in industry, and before becoming an academic, produced patents of higher quality, as measured by the number of forward citations, than patenting academics who had never worked in industry. Id. at 517 .

61. Moses III et al., supra note 50, at 181-82.

62. Arti K. Rai et al., Pathways Across the Valley of Death: Novel Intellectual Property Strategies for Accelerated Drug Discovery, 8 Yale J. Health PoL'Y L. \& ETHICs 1, 4 (2008).

63. See also Europe 2020 Flagship Initiative, supra note 12.

64. Bagley \& Tvarnø, supra note 45.

65. Notwithstanding the word "partnership," public-private partnerships "are defined and bound by contracts; they are no more and no less than the documents negotiated, approved, and executed." Julia Paschal Davis, Public-Private Partnerships, 44 Procurement L. 9, 9 (Fall 2008).

66. See Europe 2020 Flagship Initiative, supra note 12, at 14 (indicating the European Commission's position that "[c]losing these gaps, and making Europe an attractive place to invest in innovation, requires the intelligent use of public private partnerships as well as changes to the regulatory framework."). 
The parties in a PPPP must combine long-form contracting, relational governance, properly aligned incentives, and transparency to move from the Nash prisoners' dilemma equilibrium to the Pareto Optimal Frontier, that is, to create joint utility that gives each party more utility than it would have been able to generate acting alone ${ }^{67}$ This is depicted in Table 2.

Table 2: An Efficient PPPP

\begin{tabular}{|c|c|c|c|c|c|}
\hline & $\begin{array}{l}\text { Accept and } \\
\text { Abide by } \\
\text { Contract and } \\
\text { Abide by } \\
\text { Relational } \\
\text { Norms }\end{array}$ & $\begin{array}{l}\text { Reject } \\
\text { Contract but } \\
\text { Abide by } \\
\text { Relational } \\
\text { Norms }\end{array}$ & $\begin{array}{l}\text { Accept } \\
\text { Contract but } \\
\text { Deviate from } \\
\text { Relational } \\
\text { Norms }\end{array}$ & $\begin{array}{l}\text { Reject } \\
\text { Contract and } \\
\text { Deviate } \\
\text { from } \\
\text { Relational } \\
\text { Norms } \\
\end{array}$ & $\begin{array}{l}\text { Breach } \\
\text { Contract }\end{array}$ \\
\hline $\begin{array}{l}\text { Accept and } \\
\text { Abide by } \\
\text { Contract and } \\
\text { Abide by } \\
\text { Relational } \\
\text { Norms }\end{array}$ & 5,5 & & & & \\
\hline $\begin{array}{l}\text { Reject Contract } \\
\text { but Abide by } \\
\text { Relational } \\
\text { Norms } \\
\end{array}$ & & 2,2 & & & \\
\hline $\begin{array}{l}\text { Accept Contract } \\
\text { but Deviate } \\
\text { from Relational } \\
\text { Norms } \\
\end{array}$ & & & 3,3 & & \\
\hline $\begin{array}{l}\text { Reject Contract } \\
\text { and Deviate } \\
\text { from Relational } \\
\text { Norms }\end{array}$ & & & & $-2,-2$ & \\
\hline Breach Contract & $-2,4$ & & & & $4,-2$ \\
\hline
\end{tabular}

Source: Constance E. Bagley \& Christina D. Tvarnø, Pharmaceutical PublicPrivate Partnerships: Moving from the Bench to the Bedside, 4 HARV. Bus. L. REV. 389 (2014).

67. Bagley \& Tvarnø, supra note 45 , at $386-87$. 
As explained in our earlier article:

If both parties agree to a well-drafted binding contract and abide by relational norms, then they both have a positive utility of 5 . These payoffs are arbitrary numbers whose importance is their relative value and sign. If the parties cannot agree on a contract but abide by relational norms then the joint utility $(2,2)$ would still be positive, that is, greater than it would be if there was no cooperation at all but lower than what would result for a binding contract supplemented by relational governance $(5,5)$. The same is true if there is a contract but relational norms are violated $(3,3)$. Given the critical importance of allocating intellectual property rights by contract, we are assuming that the joint utility is less in this situation, though that may not always be the case. If, however, a party breaches the contract, unless the other party waives its contract rights, this opportunistic behavior results in a loss to the nonbreaching party (say, -2), which may be compensable at least in part by damages, and ill-gotten gain by the breaching party (say, 4$).{ }^{68}$

But that is not enough to convert the "dead capital" 69 created in university laboratories by academic researchers into commercially viable products. Success requires three additional elements: (1) crafting an intellectual property regime that facilitates both new upstream discoveries and the development of tools of broad application by academic researchers; (2) giving the pharmaceutical firms funding commercialization the robust returns necessary to justify the expense of developing and testing multiple compounds and biologics, knowing that only about fifteen percent will ever move past clinical trials to governmental approval; $;^{70}$ and (3) offering university researchers adequate incentives to justify their participation in the commercialization process.

\section{THE EU INNOVATIVE MEDICINES INITIATIVE AND THE ACTION PLAN AGAINST THE RISING THREATS FROM ANTIMICROBIAL RESISTANCE}

The European Union ("EU") has enacted a variety of initiatives to facilitate the flow of discoveries from the bench to the bedside, including

68. Id. at 386-89 (discussing further how to avoid the inefficient Nash equilibrium in the Prisoners' Dilemma).

69. Hernando De Soto, The Mystery of CAPITAl: Why CAPITALiSM Triumphs In the West AND FAILS EVERYWHERE ELSE 47-48 (2000) (explaining how defined property rights make it possible to convert "dead capital" into an asset that can be sold, shared or hypothecated).

70. See Koch, supra note 22, at 274 n.89 ("Only about one in six drug candidates that enter clinical trials are ultimately submitted to and approved by the FDA, according to a study of the 50 largest companies." (quoting Pharm. RESEARCH \& MFrS. OF AM., 2011 Profile 10 (2011))). 
the Innovative Medicines Initiative ("IMI") and the Action Plan Against the Rising Threats from Antimicrobial Resistance. As Màire GeogheganQuinn, then-EU Commissioner of Research, Innovation and Science explained, the "Innovation Union" contemplated by Horizon 2020 requires "(i) excellent science, (ii) industrial leadership and (iii) [the ability to address] societal challenges.",

\section{A. Goals and Structure of the Innovative Medicines Initiative}

The IMI is Europe's largest public-private pharmaceutical development partnership. It is designed to provide socio-economic benefits to European citizens by (1) improving drug development, thereby generating faster access to better medicines, and (2) increasing investment in the European pharmaceutical R\&D industry, thereby establishing Europe as the most attractive place for pharmaceutical R\&D. ${ }^{72}$ The public party is the EU, represented by the European Commission ("EC"). The private party is the pharmaceutical industry, represented by the European Federation of Pharmaceutical Industries and Associations ("EFPIA") and its members. Among other projects, the IMI supports the European Lead Factory public-private partnership, an international consortium comprising thirty partners that have agreed to pool 500,000 chemical compounds; 300,000 compounds came from AstraZeneca, Bayer Pharma, Merck, Sanofi and three other member companies, and the balance will come from academia and smaller firms. ${ }^{73}$

Each IMI calls for a project proposal involves open competition for funding as well as multiple stakeholders, including EFPIA, private pharmaceutical and biotechnology enterprises ranging from large to small,

71. See Farewell Message-Commissioner Máire Geoghegan-Quinn, EUROPEAN COMM'N (Oct. 2014), http://ec.europa.eu/commission_2010-2014/geoghegan-quinn/headlines/news/2014/20140930farewell_en.htm; What is Horizon 2020, EUROPEAN COMM'N, http://ec.europa.eu/programmes/ horizon2020/en/what-horizon-2020 (last visited Nov. 19, 2014). Carlos Moedas became the EU commissioner for Research, Science and Innovation on November 1, 2014. See Carlos Moedas, EUROPEAN COMM'N, http://ec.europa.eu/commission/2014-2019/moedas en (last visited Nov. 19, 2014). As such, he is responsible for overseeing the EU research funding programs and Horizon 2020's contribution to the Commission's jobs, growth and investment package through the promotion of the international excellence of the EU's research and science and the strengthening of research capacities and innovation across all Member States. See id.

72. Hugh Laverty, Boosting Drug Development Through Public-Private Partnerships - The IMI Model, 5 EPMA J., Feb. 2014, at A11, http://www.epmajournal.com/content/pdf/1878-5085-5-S1A11.pdf.

73. Ben Hirschler, Drugmakers, Academics Pool R\&D in $\$ 265$ Mln EU Project, REUTERS (Feb. 7, 2013), http://www.reuters.com/article/2013/02/07/pharmaceuticals-europe-rd-idUSL5N0B65QD201 30207; European Lead Factory: An Open Innovation Experiment in Drug Discovery, SLAS ELECTRONIC LABORATORY NEIGHBORHOOD (May 28, 2013), http://eln.slas.org/story/1/98-europeanlead-factory-an-open-innovation-experiment-in-drug-discovery. 
universities, hospitals, patient organizations, and public authorities. Thus, universities and firms bid for government and industry funds to support research in areas of high medical need. All IMI contracts are subject to EU regulations, including those pertaining to the ownership of any resulting discoveries and the State aid rules, which are both discussed in Part VI.

The European Union committed to contribute $€ 1$ billion to the first phase of the IMI research program ("IMI 1"), which will be matched by private in-kind contributions of at least $€ 1$ billion from the EFPIA member companies and their affiliates. ${ }^{74}$ The public funding is directed primarily to academic and non-profit institutions. As of November 2014, forty-seven IMI 1 projects were underway with a combined budget of $€ 2$ billion. ${ }^{75}$

Phase two of the Innovative Medicines Initiative ("IMI 2") commenced in July 2014 and is slated to run for ten years. ${ }^{76}$ Building on the successes and lessons learned during IMI 1, IMI 2 seeks to develop next generation vaccines, medicines, and treatments, such as new antibiotics. $^{77}$ IMI 2 has a total budget of $€ 3.276$ billion, of which the EU will contribute up to $€ 1.638$ billion from the funds authorized for Horizon 2020 . $^{78}$ EFPIA has committed to provide $€ 1.425$ billion through in-kind contributions, $^{79}$ and other life science industries may contribute an additional $€ 213$ million, either as partners in individual projects or as IMI 2 members. ${ }^{80}$

74. The IMI Joint Undertaking Model Grant Agreement Annex II - General Conditions defines "in-kind" as "contributions to the project by European Federation of Pharmaceutical Industries and Associations (EFPIA) companies and their affiliated entities, with resources such as personnel, equipment, consumables, declared in accordance with Articles II.4, II.13 and II.14." INNOVATIVE MEdicines Initiative, IMI Joint Undertaking Model Grant AGREement ANNEX II - GeneraL Conditions 2 (2012) (on file with authors); see InNOvative Meds. Initiative, ConNeCting People, Sharing KNOW-How, SPEEding UP HEAlth RESEARCh: JoIN THE PARTNERship 3 (2013), http://www.imi.europa.eu/sites/default/files/uploads/documents/IMI\%20Brochure-Dec2013-WebSpread.pdf.

75. See Anti-Biopharmaceutical Immunization: Prediction and Analysis of Clinical Relevance to Minimize the Risk, IMI ONGOING PROJECTS, http:/www.imi.europa.eu/content/ongoing-projects (last visited Nov. 26, 2014); Introducing IMI, INNOVATIVE MEDS. INITIATIVE [IMI], http:// www.imi.europa.eu/content/mission (last visited Dec. 12, 2014) ("IMI was launched in 2008 and currently has over 50 projects, with more in the pipeline.”).

76. IMI - The Story so Far, IMI, http://www.imi.europa.eu/content/history (last visited Aug. 24, 2015).

77. IMI 2, IMI, http://www.imi.europa.eu/content/imi-2\#Budget (last visited Dec. 12, 2014).

78. Id.

79. Id.

80. Id. 


\section{B. Ownership of IMI-Funded Inventions}

Article 41 of Regulation (EU) No. 1290/2013 provides that the results of an IMI-funded research project are owned by the participant that generated them. If, however, the participants make joint contributions to the final result that cannot be differentiated, then the participants will jointly own the results. ${ }^{81}$ Similarly, if it is not possible to separate the jointly-owned results for the purpose of applying for, obtaining, or maintaining the relevant intellectual property rights protection, then the participants will jointly own the intellectual property rights. ${ }^{82}$ Article 41 requires joint owners to enter into an agreement regarding the allocation of rights and the terms governing the exercise of their joint ownership in accordance with their obligations under the grant agreement. ${ }^{83}$ The joint owners may elect not to continue to hold the rights jointly. They may, instead, enter into an alternative contractual arrangement by, for example, transferring their ownership shares to a single owner who agrees to grant access rights to the other participants once the results are available. ${ }^{84}$

In contrast with the multi-participant IMI framework, the Pfizer Centers for Therapeutic Innovation ${ }^{85}$ and other comparable PPPPs in the United States involve a single private pharmaceutical firm that solicits proposals from academic scientists for research to be funded by the private firm. The private firm forms an assessment committee that evaluates the proposals with the goal of developing the firm's business without the involvement or intervention of competitors or pharmaceutical industry trade associations. Often, the pharmaceutical firm becomes the sole owner of the pharmaceutical patent through an assignment of inventions or, if the patent belongs to the researcher or the university, the firm becomes the exclusive licensee of the invention.

C. Action Plan Against the Rising Threats from Antimicrobial Resistance

In 2011, the European Commission launched another type of pharmaceutical development initiative called the Action Plan Against the Rising Threats from Antimicrobial Resistance. In response, AstraZeneca and GlaxoSmithKline announced that they would jointly contribute a total

81. See Regulation, 1290/2013 of Dec. 11, 2013, 2013 O.J. (L 347) 81 (EU).

82. Id.

83. Id.

84. See id

85. Centers for Therapeutic Innovation, PFIZER, http://www.pfizer.com/research/rd_partnering/ centers_for_therapeutic_innovation (last visited Nov. 19, 2014). 
of $€ 224$ million to develop new antibiotics. ${ }^{86}$ Both firms agreed to share information and to contribute compounds to the venture. This private joint venture involving two direct competitors collaborating to meet the public demand for new antibiotics offers a possible model for the horizontal private-private pooling of resources. ${ }^{87}$

\section{THE U.S. NATIONAL CENTER FOR ADVANCING TRANSLATIONAL SCIENCES AND OTHER U.S. PROGRAMS}

Like the European Union, the United States has created several vehicles to promote translational medicine. The National Institutes of Health in the United States established the National Center for Advancing Translational Sciences ("NCATS") in 2011, which for fiscal year 2015 had a budget request of $\$ 657$ million. ${ }^{88}$ The NCATS Strategic Alliances Office is designed "to make it easy for industry and academia to interact and partner with NCATS laboratories and scientists" by, among other things, "negotiating standard forms and model agreements between NCATS and outside parties, including universities, pharmaceutical companies and biotechnology companies" in the United States. ${ }^{89}$ According to the European Federation for Pharmaceutical Sciences (EUFEPS), which "represent[s] the interests of scientists in industry, academia, government and other institutions engaged in drug research, development, regulation and policymaking through Europe," 90 Europe will need to pursue similar

86. Amy Ritter, Public-Private Partnerships Step Up, PharmTech Talk (May 30, 2012), http://blog.pharmtech.com/2012/05/30/public-private-partnerships-step-up/.

87. Rai et al., supra note 62, at 5. Rai and her coauthors propose a two-step arrangement whereby direct competitors could put their proprietary and secret small molecules into a pool, managed by a trusted intermediary, where they would be tested in secret via high-throughput screening against assays contributed by academic researchers. If the screening revealed a "hit," that is, "molecules that showed significant activity against the target in question [that] could lead to new drug candidates," then "the contributing firm would have an obligation to provide relevant structural information to the academic via the intermediary." $I d$. at 22 . Similarly, the academic participant would be required to disclose to the firm that owned the molecule "a general statement of the methodology used to develop its target," again via the intermediary. $I d$. at 23 . This arrangement has the benefit of making it possible for researchers to run their assays against a wide range of molecules owned by a variety of firms. If there were a match, then the academic would commence second-tier negotiations in hopes of reaching a mutually acceptable agreement for the licensing of the target to the firm owning the relevant molecule. If the parties were unable to reach an agreement, then both the molecule and the target would still be protectable trade secrets by their respective inventors and thus still eligible for a future patent. $I d$. at 25 .

88. Budget, NAT'L CTR. FOR AdVANCING TRAnSlational SCI. [NCATS], http://www.nc ats.nih.gov/about/budget/budget.html (last visited Nov. 19, 2014).

89. Strategic Alliances, NCATS, http://www.ncats.nih.gov/research/tech-transfer/alliances.html (last visited Nov. 19, 2014).

90. About, EUROPEAN FED’N FOR PHARM. SCI., www.eufeps.org/about (last visited Nov. 19, 2014). 
initiatives to support the IMI research agenda and to retain its competitive advantage in pharmaceutical innovation. ${ }^{91}$

In 2014, the NIH announced the Accelerating Medicines Partnership between the NIH and ten major pharmaceutical firms that agreed to share tissue and blood samples as well as data in hopes of identifying targets for new drugs to treat Alzheimer's, lupus, rheumatoid arthritis, and type 2 diabetes. The five-year collaboration, which is supported by $\$ 230$ million in federal funding, is dedicated to decoding the biology behind these diseases. As NIH Director Francis Collins explained: "A drug company really wants to know where it should put its next billion-dollar bet in a new area of therapeutics." 92

The NIH announced in 2015 that the patients and patient advocacy organizations involved in the Precision Medicine Initiative ("PMI") will be invited to work with "academic medical centers, clinicians, scientists from multiple disciplines with creative ideas about how to make this unique opportunity successful, pharmaceutical companies and medical product developers, scientific societies and research coalitions, privacy experts and medical ethicists." ${ }^{93}$ Among the larger genome sequencing companies that could benefit from the PMI announced in 2015 are Roche Holding AG; Illumina Inc., which has an alliance with defense contractor Lockheed Martin for genomics development; and Thermo Fisher Scientific. ${ }^{94}$ Meanwhile, both IBM and Google are among large firms expected to help store and interpret genomic and other data as well as electronic health records. ${ }^{95}$

\section{UNIVERSITY TECHNOLOGY TRANSFER}

Understanding the benefits and challenges of public-private cooperation in the development and commercialization of new drugs requires an appreciation of the roles played by governments, universities, and private firms. The first step in the development of a new drug in both the United States and Europe is frequently R\&D done by a university and

91. Gaspar et al., supra note 3, at 982.

92. Monica Langley \& Jonathan D. Rockoff, Drug Companies Join NIH in Study of Alzheimer's, Diabetes, Rheumatoid Arthritis, Lupus, WALL ST. J. (Feb. 3, 2014), http://www.wsj.com/articles/SB10 001424052702303519404579353442155924498.

93. Participation, NAT'L InST. OF HEALTH, http://www. nih.gov/precisionmedicine/who.htm (last reviewed Feb. 9, 2015).

94. Sharon Begley \& Toni Clarke, Obama's 'Precision Medicine' Plan to Boost Research, but Faces Hurdles, REUTERS (Jan. 28, 2015), http://www.reuters.com/article/2015/01/28/us-healthprecisionmedicine-idUSKBN0L10D720150128.

95. Id. 
supported by government funds. ${ }^{96}$ Universities in both the United States and the EU frequently work with the private sector to commercialize their researchers' discoveries. ${ }^{97}$ This is done both informally and formally. Informal mechanisms include scientific publications and presentations, as well as social networking between scientists and practitioners, ${ }^{98}$ which results in the exchange of ad-hoc advice and academic access to industrial know-how and facilities. ${ }^{99}$ Formal mechanisms include research contracts, professorial consulting engagements, licenses, and patent agreements. ${ }^{100}$

The European Technology Transfer Offices circle ("European TTO circle") likened European technology transfer to "an emerging industry: many valuable product ideas; a highly fragmented landscape; a lack of critical mass; wide disparities in terms of performances and developing practices." 101 This lackluster performance is due in part to an academic culture that has not historically valued commercialization ${ }^{102}$ and to uncertainty concerning who actually owns intellectual property stemming from government-funded research. ${ }^{103}$ As the European Commission recognized, the EU needs to take action to "unlock the potential of IPRs

96. See Field, supra note 21, at 12.

97. See Lawson, supra note 60, at 509.

98. See Francesco Lissoni et al., Small Worlds in Networks of Inventors and the Role of Academics: An Analysis of France, 20 INDUSTRY \& INNOVATION 195, 197, 217 (2013) (finding that the presence of academic inventors and inventors from Centre National de la Recherché Scientifique ("CNRS"), the preeminent French public research organization, in company technological teams leads to "fast and widespread diffusion of technical and scientific knowledge," especially in the fields of Pharmaceuticals and Biotechnology, and Chemicals and Materials). As Lissoni et al. point out, "Academic and CNRS inventors contribute to inventive activity not only in a direct way (that is, through the patents they produce) but also through their mobility across organizations, which may lead to knowledge diffusion and further inventive activity." Id. at 217.

99. Grimaldi et al., supra note 13, at 1046-47.

100. Such agreements are often negotiated by university technology transfer offices ("TTOs"), also called technology licensing offices. Id.

101. European Technology Transfer Offices Circle, EUROPEAN COMM'N, https://ec.europa.eu/ jrc/en/tto-circle (last updated Apr. 30, 2014).

102. As Michael S. Mireles explained, "the Bayh-Dole Act may not be successful in Europe and Japan - success judged by increased patenting and licensing - because of the differences in the history, practice, and structure of most European and Japanese university systems compared with the U.S. university system. It may take substantial change in the practice and structure of European and Japanese university systems for legislation similar to the Bayh-Dole Act to be successful." Michael S. Mireles, Adoption of the Bayh-Dole Act in Developed Countries: Added Pressure for a Broad Research Exemption in the United States?, 59 ME. L. Rev. 259, 261 (2007).

103. See Jerome H. Reichman \& Rochelle Cooper Dreyfuss, Harmonization Without Consensus: Critical Reflections on Drafting a Substantive Patent Law Treaty, 57 DUKE L.J. 85, 119 (2007) ("[W]hat any given country views as 'best practices' in patent law may reflect other practices in other laws - including copyright, trade secret, utility model laws, and, above all, competition laws - that may vary widely from one country to another."). 
[intellectual property rights] that lie dormant in universities, research institutes and companies." ${ }^{104}$ We agree.

Although the U.S. Bayh-Dole Act, ${ }^{105}$ which facilitates the transfer of technology from U.S. universities to private industry, would give needed clarity to the ownership of inventions created by public institutions in the $\mathrm{EU}$, we believe that wholesale copying of the Bayh-Dole approach in the EU would be a mistake. Indeed, there are aspects of the EU licensing regime for biotechnology patents that are instructive for U.S. policy makers. Accordingly, we discuss both the U.S. and European technologytransfer regimes and compare academic patenting in the United States and EU before making our recommendations in Part VI.

\section{A. Laws Regulating Technology Transfer in the United States}

Prior to the enactment of the U.S. Bayh-Dole Act in $1980,{ }^{106}$ neither scientists nor universities in the United States could patent federally funded inventions. ${ }^{107}$ "Under the 'commons' model, the federal government sponsored basic research and encouraged its widespread publication in the public domain without regard for potential commercial applications."

104. Europe 2020 Flagship Initiative, supra note 12, at 19.

105. Thomas J. Siepmann, The Global Exportation of the US Bayh-Dole Act, 30 U. DAYTON L. REv. 209 (2004). See also Econ. Policy Comm., Working Grp. on Research \& Dev., Report on Research and Development, EPC/ECFIN/01/777-EN Final (Jan. 22, 2002).

106. Patent and Trademark Law Amendments Act (Bayh-Dole Act) of 1980, Pub. L. No. 96-517, 94 Stat. 3015 (codified as amended at 35 U.S.C. $\$ \S 200-12$ (2012)). That same year, Congress enacted the Stevenson-Wydler Technology Innovation Act of 1980, Pub. L. No. 96-480, 94 Stat. 2311 (codified as amended at 15 U.S.C. $\S \S 3701-22$ (2012)), which gave federal research laboratories the right to transfer technology developed in the government lab to a nongovernment entity, such as a private university or a for-profit firm. The Federal Technology Transfer Act of 1986 amended the StevensonWydler Act and broadened the authority of agencies to enter into a cooperative research and development agreement (CRADA) with non-federal partners. Pub. L. No. 99-502, 100 Stat. 1785 (codified as amended at 15 U.S.C. $\S 3701$ (2012)). CRADAs are "partnerships that allow for joint development with a negotiated set of contributions, responsibilities, and remuneration involving each party." Field, supra note 21, at 24. Both the government agency and the private partner can contribute services, personnel, and property, but only the private party may contribute money. The government can license the technology to the private firm in exchange for a royalty or waive its ownership rights. Id. For example, in 1991 NIH entered into a CRADA with Bristol-Myers Squibb (BMS) for the anticancer drug Taxol; under the terms of a 1996 licensing agreement, BMS paid NIH a royalty of $0.5 \%$ of BMS's revenues from sales of the drug. Id. at 60 .

107. David C. Hoffman, A Modest Proposal: Toward Improved Access to Biotechnology Research Tools by Implementing a Broad Experimental Use Exception, 89 CORNELL L. REV. 993, 997 (2004). See also Rebecca S. Eisenberg, Public Research and Private Development: Patents and Technology Transfer in Government-Sponsored Research, 82 VA. L. REV. 1663, 1663-66 (1996).

108. Hoffman, supra note 107, at 997. 
Accordingly, the results of research funded with government grants became part of the public domain or were subject only to nonexclusive licenses. ${ }^{109}$

\section{The Bayh-Dole Act}

The purpose of the Bayh-Dole Act was to facilitate the commercialization of government-funded research by establishing a uniform set of rules for designating ownership of federally funded inventions. The Act creates a presumption "that universities own inventions that are developed under their watch." 110 To promote commercialization, especially of inventions that require substantial additional R\&D and testing to get to market, ${ }^{111}$ Bayh-Dole requires universities (and other non-profit grantees) to seek to commercialize federally funded research through patents and licensing or to offer to give the exclusive rights to the invention back to the government. ${ }^{112}$ "[N]onprofit organizations may retain exclusive title to inventions developed with federal funding, and may freely license such inventions, so long as all resulting profits are used to fund additional

109. Id. at 1004-06. In contrast, "in Canada, since time in memorial [sic], almost since the Flintstones were pushing their stone wheel bicycles around, the universities have had control of the intellectual property. It was up to them to decide or negotiate with their faculty whether it was owned by the inventor or the university." Thomas Brzustowski, Government Assistance to and Policy Toward Innovation, 32 CAN.-U.S. L. J. 40, 49 (2006). Canada not only gives universities the right to keep the profits generated by the commercialization of government-funded research, it also actively encourages commercialization and provides financial incentives to "support academic institutions in identifying intellectual property with commercial potential and forging partnerships with the private sector to commercialize research results." Jocelyn Downie \& Matthew Herder, Reflections on the Commercialization of Research Conducted in Public Institutions in Canada, 1 McGill Health L. PUBL. 23, 27-28 (2007) (quoting Executive Summary: Achieving Excellence, Gov'T OF CANADA).

110. Robert M. Yeh, The Public Paid for the Invention: Who Owns It?, 27 BERKELEY TECH. L.J. 453, 453-54 (2012). Although universities may be entitled to patent rights, disputes may arise as to which university first filed for a particular patent. In 2015, a patent for the CRISPR-Cas9 genome editing technology was awarded to Dr. Feng Zhang, a scientist at the Broad Institute and the Massachusetts Institute of Technology. One potential use for this technology is helping to "rewrite flawed genes in people, opening tremendous new possibilities for treating, even curing, diseases." Andrew Pollack, The Gene Editor, N.Y. TIMES, May 12, 2015, at D1. In April 2015, the University of California, Berkeley, requested that the U.S. Patent \& Trademark Office review the patent award, arguing that Dr. Jennifer A. Doudna, a biochemist at the university, and the University of California were the first to file for the patent. The patent rights are expected to be "highly lucrative," and both scientists have formed competing companies with rights to their patents and pending patents. Id. "[This] high-profile legal fight could end up reflecting badly on the universities, who all used public tax dollars or philanthropic gifts to make the inventions." Antonio Regalado, CRISPR Patent Fight Now a WinnerTake-All Match, MIT TECH. REV. (Apr. 15, 2015), http://www.technologyreview.com/news/536736/ crispr-patent-fight-now-a-winner-take-all-match/.

111. Hoffman, supra note 107, at 1007 n.96.

112. 35 U.S.C. $§ 202(c)(3)$; see also Sean O'Connor et al., Legal Context of University Intellectual Property and Technology Transfer (paper commissioned by The Nat'l Acads. of Scis., Eng'g, \& Med., Sept. 20, 2010), http://sites.nationalacademies.org/cs/groups/pgasite/documents/webpage/pga_058 897.pdf. 
scientific research and development." 113 In short, in exchange for patenting government-funded inventions, both public and private universities in the United States can charge and retain licensing fees and royalties. ${ }^{114}$ Thus, if a university elects to retain title to a government-funded invention, "the individual inventor (who is typically employed by the institution) has no further rights." ${ }^{115}$ As discussed below, the university is, however, required to share royalties with the inventor. ${ }^{116}$

The Act requires that all universities that enter into research funding contracts with a federal agency "disclose each subject invention to the Federal agency within a reasonable time after it becomes known to contractor personnel responsible for the administration of patent matters." ${ }^{117}$ To meet this requirement, universities generally require all researchers to disclose all inventions to the university's technology transfer office. The institution has two years from the time it discloses the government-funded invention to the federal agency to decide whether the institution wants to retain title. ${ }^{118}$ If the institution decides to retain title, it must make a written election to that effect. ${ }^{119}$ The Act also states " $[t]$ hat the Federal Government may receive title to any subject invention in which the contractor does not elect to retain rights or fails to elect rights within such times." 120

Although the government has a "march-in" right to circumvent a patent when a product is "potentially lifesaving," it has apparently never been exercised. ${ }^{121}$ In addition, federally funded researchers are required to grant the federal government a nonexclusive license to use federally funded inventions. ${ }^{122}$ Once the patent expires, the invention becomes part of the public domain.

113. Fenn v. Yale Univ., 393 F. Supp. 2d 133, 137 (D. Conn. 2004) (citing 35 U.S.C. § 202(a), and 37 C.F.R. $\S 401.14(\mathrm{~b})$ ) (stating that "[ $]$ ]he Contractor may retain the entire right, title, and interest throughout the world to each subject invention subject to the provisions of this clause and 35 U.S.C. $\S$ 203").

114. DAVID C. MOWERY ET AL., IVORY TOWER AND INDUSTRIAL INNOVATION: UNIVERSITYIndustry TECHNOLOgY TRANSFER BEFORE AND AFTER THE BAYH-DOLE ACT 43-46 (2004).

115. Fenn, 393 F. Supp. 2d at 137.

116. 35 U.S.C. $\S 202(c)(7)(B)$.

117. 35 U.S.C. $\S 202(\mathrm{c})(1)$.

118. 35 U.S.C. $\S 202(\mathrm{c})(2)$.

119. Id.

120. Id.

121. Field, supra note 21, at 24 n.124; Hoffman, supra note 107, at 999, 1008 ("In the presumably infrequent cases in which 'a licensee fail[ed] . . to commercialize [a] technology,' the Act allowed a third party to petition the government for the right to license it for commercial purposes.... Unsurprisingly, the federal government has never exercised its 'march-in' rights.").

122. 35 U.S.C. $\S 202(c)(4)$. 
2. Employers' Rights to Inventions Created by Employees Hired to Invent and Contractual Assignments of Inventions

U.S. patent law's "hired-to-invent" doctrine gives an employer the right to all inventions developed by employees specifically hired to invent. The hired-to-invent doctrine requires that the employee-inventor assign the invention to the employer, even in the absence of a written agreement requiring such an assignment. ${ }^{123}$ In the case of inventions by employees not hired to invent, the employer may still obtain the rights to employee inventions as a matter of contract through an assignment of inventions, ${ }^{124}$ which employees are often required to sign before beginning work.

Many U.S. universities require that researchers assign their inventions to the university regardless of the source of funding. For example, the Technology Licensing Office at the Massachusetts Institute of Technology ("M.I.T.") issued the following policy statements:

Patents, copyrights on software, maskworks, and tangible research property and trademarks developed by faculty, students, staff and others, including visitors participating in M.I.T. programs or using M.I.T. funds or facilities, are owned by M.I.T. when either of the following applies:

1. The intellectual property was developed in the course of or pursuant to a sponsored research agreement with M.I.T.; or

2. The intellectual property was developed with significant use of funds or facilities administered by M.I.T. ...

123. Joshua L. Simmons, Inventions Made for Hire, 2 N.Y.U. J. InTELL. Prop. \& ENT. L. 1, 14-15 (2012). Title does not immediately vest in the employer upon invention. Id. at 15. Factors a court will review to determine if an inventor has been hired to invent include, for example, previous assignments of patents by the employee, customary practice in the company who originally posed the problem solved by the invention, and whether the invention was created during the period of employment. Id. at 15 n.55; see also William C. Lewis, Hey! You Stole the Invention I Paid You to Invent!, NEXSEN PRUET LLC (Oct. 13, 2011), http://www.martindale.com/labor-employment-law/article_Nexsen-PruetLLC_1358040.htm ("The 'hired to invent' doctrine is an exception to the rule that an inventor owns all rights to the invention. In general, someone hired to invent something who succeeds in accomplishing the task during the performance of the contract is bound to assign all rights to the invention to the person that hired them.").

124. Assignment agreements vary in their terms. For example, some include "unconditional general assignment" policies obligating staff to assign all inventions; some agreements assign rights "only for special projects or sponsored research," and some determine ownership on a case-by-case basis. See Sean M. O'Connor, The Real Issue Behind Stanford v. Roche: Faulty Conceptions of University Assignment Policies Stemming from the 1947 Biddle Report, 19 MiCH. TELECOMM. \& TECH. L. REV. 2, 379, 393 (2013).

125. Part 2: MIT Policy Statements, § 2.1, Mass. InSt. of TeCh. TeCh. Licensing Office, http://tlo.mit.edu/community/policies/part2 (last visited July 13, 2015) [hereinafter M.I.T. POLICIES]. 
It goes on to provide:

PATENTS: Research contracts sponsored by the Federal Government are subject to statutes and regulations under which M.I.T. acquires title in inventions conceived or first reduced to practice in the performance of the research. M.I.T.'s ownership is subject to a nonexclusive license to the government and the requirement that M.I.T. retain title and take effective steps to develop the practical applications of the invention by licensing and other means. Contracts with industrial sponsors provide that M.I.T. retain ownership of patents while the sponsor is granted an option to acquire license rights. ${ }^{126}$

Universities aggressively protect their rights to employees' inventions, as illustrated by Fenn v. Yale University. ${ }^{127}$ Yale University Professor and Nobel laureate in Chemistry John B. Fenn was issued United States Patent No. 5,130,538 ('538 patent) on July 14, 1992 for a chemical mass spectometry invention. In 2003, the U.S. District Court for the District of Connecticut concluded that Fenn had breached Yale's internal patent policy, under which he was "contractually bound and which gave the university right of first refusal to patent any faculty inventions." "128 The court found that Fenn's failure to be "straightforward" with the university induced Yale not to assert its ownership rights, giving Fenn the opportunity to secretly file the application himself. In 2005, the court went further, holding that Yale was entitled to treble damages because Fenn had committed conversion and statutory theft. ${ }^{129}$ In addition, the Court ordered Fenn to assign his interests under the ' 538 patent to Yale, as required under Yale's 1989 patent policy. The court wrote that Fenn could not profit from his own wrongdoing and that the patent could be reassigned to Yale, its rightful owner. ${ }^{130}$ Fenn was ordered to pay Yale $\$ 545,000$ in royalties as well as Yale's legal costs of almost $\$ 500,000$. $^{131}$

126. Id. $\S 2.1 .1$.

127. See generally Fenn v. Yale Univ., 2005 WL 327138 (D. Conn. Feb. 8, 2005).

128. Id. at $* 2$.

129. Id. at $* 4$.

130. Id. at *6.

131. Marius Meland, Judge Rules for Yale in Patent Dispute with Former Professor, LAw360 (Feb. 15, 2005), http://www.law360.com/articles/3016/judge-rules-for-yale-in-patent-dispute-withformer-professor. For his part, Fenn had testified that he had filed his own patent on May, 19, 1989 "in an attempt to "show up how [Yale] handled its business, which in my view was incompetent." Fenn, 2005 WL 327138, at *4. Yale's Office of Collaborative Research had not filed a patent application covering Fenn's invention by May 19, 1989, even though the last day to file for a patent was June 1, 1989. Id. 
State labor laws impose some limits on an employer's ability to require employees to assign all inventions. For example, California law provides that an employer may not require an employee to assign an invention that the employee developed entirely on his or her own time without using the employer's equipment, supplies, facilities, or trade secret information except for those inventions that either (1) relate to, at the time the invention was conceived or reduced to practice, the employer's business or the actual or demonstrably anticipated research or development of the employer; or (2) result from any work the employee performed for the employer. ${ }^{132}$ However, this limited carve-out will not prevent universities from laying claim to most university researchers' inventions.

\section{Compensation for Inventors}

The Bayh-Dole Act includes a provision requiring a non-profit contractor to share royalties with the inventor. ${ }^{133}$ However, it neither dictates the percentage of royalties that must be paid to the inventor, ${ }^{134}$ nor prescribes a minimum payment. ${ }^{135}$ Instead, "[t]he provision that non-profit institutions share royalties was included merely to ensure that inventors were provided with an adequate incentive to engage in scientific research." ${ }^{136}$ Congress intended that "any sharing ratio should be left to the supply and demand of the market."137

It is, therefore, not surprising that royalty agreements vary by university or research institute. Certain institutions share a fixed percentage of the revenue (after deducting specified costs) generated from licensing the technology, while others implement a sliding scale system whereby the percentage of revenues paid out declines as the amount of revenue increases. ${ }^{138}$

For example, Sloan-Kettering Institute for Cancer Research pays its inventor-employees five percent of the royalties it receives from their

132. CAL. LABOR CODE $\S 2870$ (a) (West 2015).

133. 35 U.S.C. $\$ 202(\mathrm{c})(7)(B)$.

134. Alan S. Gutterman, Bayh-Dole Act-Royalty Sharing Requirements, in BUSINESS TRANSACTIONS Solutions § 209:24, Westlaw (database updated Sept. 2015).

135. Platzer v. Sloan-Kettering Inst. for Cancer Res., 787 F. Supp. 360, 368 (S.D.N.Y. 1992) (holding that "Congress' concern was with the reinvesting of funds to further research, not with furthering the private interests of individual inventors").

136. Id.

137. Id.

138. Gutterman, supra note 134, § 209:24. 
inventions pursuant to a sliding scale set forth in the Institute's patent policy. ${ }^{139}$ Meanwhile, Stanford University's

royalty-sharing policy provides for the distribution of cash net royalties (defined as gross royalties less 15\% for OTL's [Office of Technology Licensing's] administrative expenses, minus direct expenses) to inventors, their departments, and their schools. In 2012-13, inventors received personal income of $\$ 21.7 \mathrm{M}$, departments received $\$ 19.4 \mathrm{M}$, and schools received $\$ 18.8 \mathrm{M}$. The University assessed an infrastructure charge on the department and school shares of royalty income. ${ }^{140}$

Thus, of the $\$ 87$ million in gross royalty revenues received by Stanford in 2012-2013, the individual inventors received $25 \%$. $^{141}$

In contrast, M.I.T. distributes one third of the Adjusted Royalty Income received from licensees to the inventors. ${ }^{142}$ "Adjusted Royalty Income" is equal to the gross royalty income less (1) a $15 \%$ administrative fee and (2) out-of-pocket costs not reimbursed by the licensees, including patent filing, prosecution and maintenance fees, and certain marketing expenses. $^{143}$ If M.I.T. acquires from a company to which intellectual property is transferred "equity in lieu or partial lieu of royalties for intellectual property," any inventor who receives an equity position from that company does not share in M.I.T.'s equity. For all other inventors, M.I.T. distributes cash to the inventors upon occurrence of a liquidation event proportionate to what their cash share would have been had no equity been issued to the university. ${ }^{144}$ Although Yale University increased the percentage of net royalties paid to academic inventors from $15 \%$ to $50 \%$ in $1975,{ }^{145}$ it reduced that amount in 1984 to $30 \%$ of net royalty income up to $\$ 200,000$ and $20 \%$ of net royalty income in excess of $\$ 200,000$. $^{146}$ The University of Wisconsin, which operates one of the most successful public university technology transfer operations in the United States, the

139. Platzer, 787 F. Supp. at 362. The U.S. District Court for the Southern District of New York rejected the inventors' claim for a larger percentage. $I d$. at 368.

140. Stanford Univ. OfFice of Tech. Licensing, Translating Potential: ANNUAl Report (2013), http://otl.stanford.edu/documents/otlar13.pdf.

141. Id.

142. M.I.T. POLICIES, supra note $125, \S 4.8(\mathrm{~A})$.

143. Id.

144. Id. $\S 4.9 .2$.

145. Fenn v. Yale Univ., 283 F. Supp. 2d 615, 622 (D. Conn. 2003).

146. Id. at 623 . 
Wisconsin Alumni Research Foundation ("WARF"), 147 gives academic inventors $20 \%$ of the royalties (before expenses) earned from their discoveries. ${ }^{148}$ Although all faculty, staff, and students must disclose their discoveries and inventions to WARF, ${ }^{149}$ it does not require academic inventors to assign their inventions to the university except where required by funding agreements, as where inventions are funded in whole or in part by federal research grants. ${ }^{150}$ WARF also returns $15 \%$ of royalties to the inventors' departments to fund future research. ${ }^{151}$

\section{University Technology Transfer Offices}

University technology transfer offices function as the central clearinghouse for university-generated inventions, especially patents. ${ }^{152}$ For example, M.I.T.'s Technology Licensing Office pursues

the licensing of technology by researching the market for the technology, identifying third parties to commercialize it, entering into discussions with potential licensees, negotiating appropriate licenses or other agreements, monitoring progress, and distribu-ting royalties to the inventors/authors in accordance with M.I.T. royalty policy. When it is appropriate to do so, M.I.T. may accept an equity position in partial lieu of cash royalties. ${ }^{153}$

The returns generated by the Stanford University and the University of Wisconsin technology transfer offices, discussed below, show how significant the financial returns can be.

147. For UW Inventors, WIS. ALUMNI RESEARCH FOUND., http://www.warf.org/for-uwinventors.cmsx (last visited Jan. 21, 2015) ("Few institutions offer such generous returns, or have been as successful placing technologies and defending intellectual property.").

148. Id.

149. Id.

150. After disclosing an invention to WARF that was not federally funded (or subject to another funding agreement), the inventor "is free to dispose of the rights to the invention in the manner of his or her choosing." Ownership and Equity Review, UNIV. OF WISCONSIN-MADISON, https://research.wi sc.edu/projectagreementsip/intellectualprop/ownership/ (last visited Jan. 21, 2015). If WARF has expressed an interest in protecting the invention, the inventor may then choose to work with WARF. Id. "The UW is unique among U.S. universities in that it does not claim ownership rights in the intellectual property generated by its faculty, staff, or students, except when required by funding agreements." Intellectual Property, UNIV. OF WISCONSIN-MADISON, https://research.wisc.edu/projectagreementsip/ intellectualprop/ (last visited Jan. 21, 2015).

151. For UW Inventors, supra note 147.

152. They play a much less significant role in open source projects and informal collaborations. See generally M.I.T. POLICIES, supra note 125; For UW Inventors, supra note 147.

153. M.I.T. POLICIES, supra note $125, \S 4.1$. 
Stanford's Office of Technology Licensing (“OTL”) spent $\$ 9.3$ million on patent and other legal expenses in fiscal year 2013, of which $\$ 4$ million was reimbursed by licensees. ${ }^{154}$ Excluding patent expenses, its operating budget was $\$ 6.6$ million. ${ }^{155}$ The OTL reported that in the period from 2012 to 2013 Stanford "received $\$ 87 \mathrm{M}$ in gross royalty revenue from 622 technologies, with royalties ranging from less than $\$ 10$ to $\$ 55 \mathrm{M}$. Forty-two of the 622 inventions generated $\$ 100,000$ or more in royalties. Six inventions generated $\$ 1 \mathrm{M}$ or more." ${ }^{156}$ As of August 31, 2013, Stanford held equity in 161 companies, issued pursuant to license agreements. ${ }^{157}$

In fiscal year 2013, Stanford's Industrial Contracts Office, a part of OTL, entered into 110 new specialized research agreements with industrial firms that "fund, and sometimes collaborate on, research projects in Stanford laboratories."158 These agreements included (1) several projects funded by the global chemical company BASF with Stanford investigators in materials science using "plasma-enhanced atomic layer deposition to grow oxide layers with precise thickness control for electronics" and (2) projects funded by Boeing involving researchers in the School of Engineering "studying high-performance and reliable composite adhesive bonding for aerospace systems" and "researching fiber optical sensors and solar energy conversion for aerospace applications." 159

In the fiscal year ending June 30, 2014, the Wisconsin Alumni Research Foundation earned $\$ 43.4$ million in royalties and licensing fees and net income of $\$ 318.7$ million from its investment portfolio. ${ }^{160}$ WARF paid university inventors $\$ 11.5$ million, awarded University of Wisconsin at Madison \$59.3 million in grants, and provided a \$14.3 million grant to the Morgridge Institute for Research, a private, non-profit research center that partners with the University of Wisconsin at Madison "to explore new, uncharted scientific territory." "Since its inception in 1925, WARF has provided more than $\$ 2.3$ billion to the University of Wisconsin at Madison and the Morgridge Institute for Research "in the form of direct grants and more than $\$ 300$ million to faculty inventors, all adjusted for inflation." ${ }^{, 162}$ In

154. StANFORD UniV. OfFICE OF TECH. LiCENSING, supra note 140.

155. Id.

156. Id.

157. Id.

158. Id.

159. Id.

160. Financials, Wis. ALUMNI RESEARCH FOUND., http://www.warf.org/stewardship/financials/ financials.cmsx (last visited July 16, 2015).

161. Id.; Our Relationship with UW-Madison, MORGRIDGE INST. FOR RESEARCH, http:// morgridge.org/about/our-relationship-with-uw/ (last visited Jan. 21, 2015).

162. Financials, supra note 160. 
addition, since 1999 , it has provided more than $\$ 500$ million of in-kind support. $^{163}$

Although much of the empirical work on academic entrepreneurship has focused on patenting activities, it is important to keep in mind other forms of intellectual property protection, such as copyrights and trade secret protections, as well as open source initiatives and informal collaboration among academics and industrial researchers ${ }^{164}$ when crafting public policy and university rules.

\section{B. Laws Regulating Technology Transfer in the European Union}

The European Commission stated in 2010 that meeting the goals of the Innovation Union will require (1) giving researchers and innovators the ability "to move easily between public and private institutes," (2) clear rules on the ownership of intellectual property rights, and (3) "sharing and support systems ... to facilitate knowledge transfer and the creation of university spin-offs and to attract (venture) capital and business angels."165

1. Allocation of Ownership Rights Between the University and Its Researchers

Because the EC has not specified who owns academic inventions funded by the government, the twenty-eight Member States have established their own rules allocating the rights to intellectual property developed in university laboratories. ${ }^{166}$ These national rules vary significantly in both form and substance. Many have been amended in the last several decades to promote commercialization of university technology, in part to supplement limited government funding for public universities. ${ }^{167}$ There is also no standard legislative model in the EU or its Member States specifying the employer's and the employee's right to inventions or the employee's right to compensation. ${ }^{168}$

(1) The differing regimes within Europe mean that the original owner of IP resulting from collaborative research can be the institution, individual researchers, students, the industry partner or a combination of these.

163. Id.

164. See Antonio Della Malva et al., Institutional Change and Academic Patenting: French Universities and the Innovation Act of 1999, 23 J. EVOLUTIONARY ECON. 211, 217-18 (2013).

165. Europe 2020 Flagship Initiative, supra note 12, at 34.

166. Sanna Wolk, EU Intellectual Property Law and Ownership in Employment Relationships, 56 SCANDINAVIAN STUD. L. 419, 421 (2010).

167. Malva et al., supra note 164 , at 214.

168. Wolk, supra note 166 , at 420. 
(2) Ownership of any background knowledge necessary for the commercialization of that IP may rest with any of the parties involved in the research project, or even with third parties. ${ }^{169}$

Historically, many European countries honored the "professor's privilege," which gave faculty members the right to retain ownership of inventions created in the course of their employment. ${ }^{170}$ This exempted professors from the usual rules giving non-academic employers the right to employee inventions arising out of an employee's assigned duties. ${ }^{171}$ Certain Member States, including Sweden, continue to honor the privilege. Professors in such States own the rights to their inventions and have the ability to license them to others, including for-profit entities. ${ }^{172}$ According to the European Commission, Sweden had "the best performing innovation system in the EU [in 2013], followed by Denmark, Germany and Finland."173

The United Kingdom was the first European country to eliminate the professor's privilege. ${ }^{174}$ The United Kingdom Patent Act of $1977^{175}$ provides that academic researchers employed by a university do not own their inventions. In 1985, the U.K. went a step further and gave universities the right to patent their faculty members' inventions and license them to third parties. ${ }^{176}$ Prior to that time, a public agency, the British Technology Group, was the "nominal" owner" ${ }^{177}$ of academic discoveries. ${ }^{178}$ Austria,

169. CREST European Union SCIENTIFIC \& TeChNiCAl ReSEARCH COMM., Final Report of THE CREST OMC EXPERT GROUP ON INTELLECTUAL PROPERTY 15 (2006).

170. Malva et al., supra note 164, at 214; see infra notes 319-22 and accompanying text.

171. Malva et al., supra note 164, at 214 n.4.

172. Ashley J. Stevens \& April E. Effort, Using Academic License Agreements to Promote Global Social Responsibility, 43 LES NOUVELLES 85, 98 (2008).

173. EUROPEAN COMM'N, INNOVATION UNION SCOREBOARD 2014, at 4 (2014), http://ec.eur opa.eu/enterprise/policies/innovation/files/ius/ius-2014_en.pdf. Switzerland was the European innovation leader, outperforming all of the EU Member States. Id.

174. Malva et al., supra note 164 , at 214.

175. Patents Act, 1977, C. 37, §§39(1), 40(1), 40(2) (U.K.).

176. In 1950, Treasury Circular TC $5 / 50$ "granted the 'right of first refusal' of patents created in universities by public funds to the [National Research Development Corporation (NRDC)]." Daidree Tofano, Edwin Southern's Microarray: Policy and Intellectual Property Considerations 15 (Apr. 25, 2006) (unpublished B.A. thesis, Duke University) (available through Duke University at http://hdl.handle.net/10161/8114). NRDC later merged with the National Enterprise Board, creating the British Technology Group. Id. at 16. TC 5/50 was rescinded in 1985, effectively allowing universities to "patent and exploit" their intellectual property. Id. at 17-18. A Treasury circular serves as "guidance to governmental departments" and is not legislation. As such, it may be passed or rescinded without the approval of Parliament and is "subject to change at any time as is seen fit." Id. at 15, 17 n.71.

177. Malva et al., supra note 164, at 214.

178. Maxine Clarke, British Technology Group - UK Technology Transfer Grows, NATURE, Aug. 1,1985 , at 385 . 
Denmark, and Germany all abolished the privilege between 2000 and 2002. ${ }^{179}$ "This 'abolitionist movement' in Europe came from the wish of policymakers to recreate similar conditions to those in the U.S., where universities retain all IPRs over the results of publicly funded research." ${ }^{180}$ Italy decided to introduce the privilege in $2001{ }^{181}$ Interestingly, Austria, Denmark, Germany, and Italy all based their new laws on the need to promote commercialization. ${ }^{182}$

Certain countries, including Austria, ${ }^{183}$ France, ${ }^{184}$ Hungary, ${ }^{185}$ Italy, ${ }^{186}$

179. Malva et al., supra note 164, at 214.

180. Francesco Lissoni et al., Academic Patenting and the Professor's Privilege: Evidence on Denmark from the KEINS Database, 36 SCI. \& PUB. POL'Y 595, 595 (2009) (finding that in the first years following Denmark's abolition of the professor's privilege, a considerable amount of patenting activity moved from the professors to the universities; further finding that before and after abolition of the privilege the bulk of academic patenting consists of inventions owned by business companies).

181. Malva et al., supra note 164, at 214. Article 65 of the Italian Industrial Property Code, enforced by Legislative Decree n. 30, enacted on February 10, 2005, provides that a researcher working for a university becomes the owner of all rights related to the patented invention, and each university can determine by itself the maximum amount of royalties that are to be paid to the university by a third party who gets the license to use the invention. Country Overview: Italia - Who Owns IP in Research and Development, BIOLEGIS, http:/www.biolegis.com/uploads/tx_articles/Who_owns_IP_Natale_Tulli

Associati_2011.pdf (last visited Nov. 24, 2014) (referencing CODICE DELLA ProprietA' INDUSTRIALE [INDUSTRIAL PROPERTY CODE] art. 64, enforced by Decreto Legislativo 10 febbraio 2005, n. 30 (It.).

182. Malva et al., supra note 164, at 214.

183. Austrian Patent Law entitles an employee to an "adequate, special compensation" for assigning an invention to the employer. If the employment is regulated under civil law, the rights to employee inventions must be transferred to the employer only if the transfer was agreed to in writing. The special compensation is paid in addition to an employee's ordinary salary. The amount is determined on a case by case basis and considers the economic importance of the invention; other exploitations of the invention; and the extent to which the support of the employer's resources contributed to the invention. No additional compensation is paid to employees who are explicitly hired for inventive activities. For employment relationships that are covered by public law ("civil servants, which may also include university employees"), the employer has the right to demand the transfer of the rights to the employee's invention even if the transfer was not agreed to in writing. Public employees are also entitled to appropriate compensation for the transfer. See Compensating Employee Inventors, TAYLORWESSING (Jan. 2014), http://www.taylorwessing.com/synapse/ti_compensation_employee 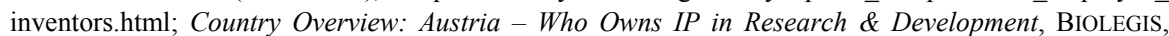 http://www.biolegis.com/uploads/tx_articles/Who_owns_IP-austria.pdf (last visited Nov. 24, 2014); PatentGesetz 1970 [PAT G] [PATENT LAw] Bundesgesetzblatt [BGBl] No. 259/1970, as amended (Austria).

184. CODE LA Propriété INTEllectuelle [C.P.I.] [INTELleCtUAl Property CODE] art. L.611-7 (Fr.). The French Innovation Act of 1999 "added explicitly the commercial exploitation of patents and licenses to the universities' mission, on the same footing as teaching and research" and made it possible for universities and public research organizations to create technology transfer offices, "to staff them with external personnel, and to run them according to business-like budgetary and accounting rules." Malva et al., supra note 164, at 218. The Ministry of Research enacted "guidelines for universityindustry cooperation, which included the recommendation to adopt an intellectual property charter (so that, especially in universities, IPR [intellectual property right] matters could be explicitly regulated) as 


\section{the Netherlands, ${ }^{187}$ Poland, ${ }^{188}$ Portugal, ${ }^{189}$ and Spain, ${ }^{190}$ include employee inventor compensation provisions in their national patent legislation, while}

well as negotiation with companies of 'joint ownership agreements' over the results of collaborative R\&D.” Id.

185. An employee invention is defined as "an invention made by a person who, without being under an obligation by reason of his employment, makes an invention, the exploitation of which falls within the field of business of his employer.” 1995. évi XXXIII. törvény a Találmányok Szabadalmi Oltalmáról, art. 9(2) (Act No. XXXIII of 1995 on the Protection of Inventions by Patents) (Hung.), translation at http://www.wipo.int/edocs/lexdocs/laws/en/hu/hu048en.pdf. "Remuneration for the right to exploit an employee invention shall be paid by the employer," and the remuneration amount for that right "shall be equal to that which would be payable by the employer for a license, on the basis of a patent license agreement," after considering licensing conditions in the field of the invention. Id. art. 14. "Universities and third parties usually conclude research agreements under the Hungarian Civil Code" where the obligor performs research services and the sponsor pays remuneration; "[i]n practice, the parties agree that the sponsor of the research acquires all IP rights." Country Overview: Hungary - Who Owns IP in Research \& Development, SZECSKAY, http:/www.biolegis.com/uploads/tx_articles/ Who_owns_IP_Szecskay_2011.pdf(last visited Nov. 24, 2014).

186. In Italy, when "inventions [are] produced occasionally by the employee, during his free time, by using his personal technical instruments but exploiting the know how of the employer[,]" the employee owns the rights related to the invention, but the employer has the right to use or buy the patents from the inventor. Country Overview: Italia, supra note 181. "In any case, the author will be granted not less than $50 \%$ of the total amount of the royalties deriving from the license of the invention." Id.

187. In the Netherlands, article 12 (1) of the Patent Act of 1995 provides that, in a "regular employment relationship," the person who makes the invention may claim the patent. A "more favourable rule is set out in Article 12 (3)" for universities and research institutions - if the invention is made by a university or research institution employee, the employer is entitled to the patent, but the parties may alter this by agreement. Equitable remuneration is generally required for the employee if not provided for in the employment contract. Country Overview: The Netherlands Who Owns IP in Research and Development, BIOLEGIS, http://www.biolegis.com/uploads/tx_articles/Who_owns_IPolanda.pd (last visited Nov. 24, 2014).

188. In Poland, the "default rule" for ownership of industrial property, as stated in article 11, section 3 of the Industrial Property Law of 2000, as amended, is that the employer owns industrial property created by an employee, unless otherwise agreed. IP Management, Cooperation Between EU \& Strategic Partners, Poland, HEIP-LINK, http://www.heip-link.net/content/subject/poland (last visited Nov. 25, 2014). When an invention is made by a creator with the help of an economic entity, the economic entity may enjoy the right to exploit the invention in its own field of development. Id. (referencing article 11, section 5 of Industrial Property Law of 2000).

189. Industrial property law covers patent innovation in Portugal. If "inventive activity is provided for" in an employment contract, the patent belongs to the company, and the inventor is entitled to remuneration. Country Overview: Portugal - Who Owns IP in Research \& Development, BIOLEGIS (Oct. 2011), http://www.biolegis.com/uploads/tx_articles/Who_owns_IP_CRA_Law_2011.pdf (referencing CÓdigo DA PROPRIEDADE INDUSTRIAL (C.P.I.) (INDUSTRIAL PROPERTY CODE) (Port.)).

190. Article 17 of the Spanish Patent Act states that if an employee made an invention "related to his professional activity in the company and the knowledge acquired into the company had influenced predominantly his invention or he had utilized company's means to achieve it, the employer would have the right to the invention's ownership or to reserve a right to use the invention for himself," and the worker is entitled to a fair economic compensation. Country Overview: Spain - Who Owns IP in Research \& Development, BIOLEGIS, http://www.biolegis.com/uploads/tx_articles/Who_owns_IP Spain.pdf (last visited Nov. 24, 2014). 
Denmark, ${ }^{191}$ Finland, ${ }^{192}$ Germany, ${ }^{193}$ and Norway ${ }^{194}$ have enacted specific employee compensation laws. ${ }^{195}$ In contrast, other countries apply general principles of labor law. As a result, there is a non-transparent and nonuniform system for determining who owns university inventions created in the EU.

For example, the German Employees' Inventions Act provides that a university can claim exclusive rights to employment inventions created by university researchers and research associates working on its campus using government funding. ${ }^{196}$ Section 4 of the Act defines employment inventions "as those, that are made during the duration of the service or employment contract, and that have either developed from such activities of the inventor as were part of his work, or which are significantly based on

191. Bekendtgørelse af lov om arbejdstageres opfindelser (Consolidate Act. No. 104 on Employees' Inventions), Jan. 24, 2012, § 5 (Den.); Bekendtgørelse af lov om opfindelser ved offentlige forskningsinstitutioner (Consolidate Act. No. 210 on Inventions at Public Research Institutions), Mar. 17, 2009, § 8 (Den.).

192. In Finland, the Act on the Right in Employee Inventions provides that an employee shall have the same rights to his or her invention as other inventors, unless otherwise provided by legislation. Generally, an employee owns all rights to an invention created by him or her; a specific procedure and assignment is required to render the invention the property of the employer. The employee is entitled to a "reasonable compensation" if the employer decides to assume the rights to an invention. Linda Berggren, Finland: Employee Inventions, BORENIUS LTD. (Feb. 7, 2008), http://www.mondaq.com/x/ 55254/employee+rights+labour+relations/Employee+Inventions. The law applies to both private and public employment and its provisions are "mainly non-mandatory," meaning it applies only in the absence of a separate contractual arrangement. Id. The Employee Invention Act does not apply to university researchers, whose rights are provided by the Act on the Right in Inventions Made at Higher Education Institutions (University Inventions Act). This law "extends the possibility for universities to assume the rights of inventions conceived within the domain of the institution"; prior to the law, the researchers were entitled to retain the rights to their inventions, unless otherwise agreed. If the research involves a party outside the university (collaborative research), the university has the right to acquire the right to the invention. For research not involving outside parties (open research), the inventor may retain the right to the invention. If the university acquired rights to the invention, the researcher is entitled to a "reasonable compensation," the amount of which is determined on a case-by-case basis. Id.

193. Gesetz über Arbeitnehmererfindungen [ArbNErfG] [Employees' Inventions Act], July 25, 1957, BGBL. I at 756, last amended by Gesetz [G], July 31, 2009, BGBL. I at 2521, ch. 2, § 6 (Ger.).

194. The Norwegian Employee Invention Act provides that when an invention results from a specified task assigned to an employee as part of his or her employment, the employer is "entitled to have all or part of the rights to the invention transferred to it if the exploitation of the invention comes within the sphere of the company's activity." Ingeborg Moen Borgerud et al., Employment and Employee Benefits in Norway: Overview, PrACTICAL L. (Aug. 1, 2012), http://us.practicallaw.com/3507-2636\#a358906. The employee has the right to be compensated for patentable inventions that are transferred. The Employee Invention Act can be modified by contract, but the right to compensation cannot be eliminated. Id.

195. See Maximilian Haedicke, Ownership, in PATEnT LAw: A HandBook On European And German PATENT LAW 242, 242 (Maximilian Haedicke \& Henrik Timmann eds., 2013).

196. Gesetz über Arbeitnehmererfindungen [ArbNErfG] [Employees' Inventions Act], ch. 3, § 42 (Ger.). 
experiences or work of the university." 197 The Act requires the employee to notify the employer in writing of service inventions, after which the university "as employer" may claim the right to such inventions. ${ }^{198}$ If an employer does not explicitly waive its claim to the invention within four months of the notification, the invention will belong to the employer. ${ }^{199}$ Service inventions that have been expressly released by the employer within four months, as well as free inventions (employees' inventions that "cannot be attributed to company activities") are generally at the free disposal of the employee-inventor, except that Sections 18 and 19 of the German Employees' Inventions Act require that the employee give the university notice of each invention and offer the university a nonexclusive right to make use of the invention before it is otherwise utilized. ${ }^{200}$

Several national patent acts permit universities and their researchers to allocate the ownership rights to intellectual property developed in university labs by contract, even if the research is government funded. The Danish Act on Inventions at Public Research Institutions ("DAIPRI") applies to inventions that can be patented by the Danish Patent Act. As a general rule, the right to inventions made by a university employee belongs to the employee under Section 7 of DAIPRI. ${ }^{201}$ The university may, however, pursuant to Section 8(1), claim the rights to the invention if it was made as part of the employee's work for the university. ${ }^{202}$ If the research is funded in cooperation with a party not covered by DAIPRI, the university may, "on its own and the employee's behalf," in accordance with Section 9, enter into an agreement at the outset waiving the right to the inventions, in full or in part, resulting from the research. ${ }^{203}$ Thus, in certain Member States, the legislative terms are default provisions that may be modified by

197. Patents and Licenses: The Legal Protection of Research Achievements, HuMBOLDUNIVERSITÄT ZU BERLIN (July 17, 2013), https://www.hu-berlin.de/research/transfer/patente_lizenzen/ pl_pat_rec_html [hereinafter Patents and Licenses].

198. Approaches to Compensating Inventive Employees, in the UK and Germany, OSBORNE ClARKE (Aug. 27, 2014), http://www.osborneclarke.com/connected-insights/publications/approachescompensating-inventive-employees-uk-and-germany/.

199. Id.

200. Patents and Licenses, supra note 197; Employee Inventions Law, BARDEHLE PAGENBERG, http://www.bardehle.com/en/publications/interactive_brochures/employee_inventions_law.html (last visited Nov. 5, 2015).

201. Bekendtgørelse af lov om opfindelser ved offentlige forskningsinstitutioner (Consolidate Act. No. 210 on Inventions at Public Research Institutions), Mar. 17, 2009, § 7(1) (Den.).

202. Id. $\S 8(1)$

203. Id. $\S 9(1)$. The Danish Act on Inventions at Public Research Institutions applies to universities governed by the Danish University Act, governmental research institutions, and health research institutions under the Danish regions, among others. Id. $\S 6(1)$. 
contract, as long as the contract does not conflict with the EU rules on State aid or EU competition law, which are both discussed in Part VI.

\section{Compensation for Inventors}

In the last several decades there has been heightened interest in what right, if any, researchers in university laboratories should have to share in the royalties and fees generated by their inventions. ${ }^{204}$ The EU Commission has not addressed this issue, so, as with the ownership of inventions by university scientists, the twenty-eight Member States have established differing national regimes. ${ }^{205}$ Unfortunately, these national rules vary significantly and can be difficult for a lay person (or, in some cases, even a lawyer) to parse. In addition, the rules sometimes result in an allocation of IP rights that is not economically efficient given the different utilities universities, private firms, and researchers might ascribe to commercialization. The absence of clear default rules also greatly increases transaction costs.

Historically, employee compensation for inventions was awarded in certain EU Member States, including the United Kingdom, only in "exceptional circumstances." "206 For example, the UK Patents Court awarded two inventors at GE Healthcare Limited total compensation of approximately $€ 1.5$ million in Kelly v. GE Healthcare, ${ }^{207}$ but only because the patent was of outstanding benefit to the employer. Certain experts predict that "compensation in the UK is likely to continue to be an exception rather than the rule, with only claims regarding particularly profitable products having a good chance of success." 208

However, a university can contract to give its researchers a share of royalties and licensing fees. For example, the University of Oxford has "a generous revenue-sharing policy" that "brings significant personal benefits to researchers."209 Similarly, Danish patent laws permit the splitting, pursuant to contract, of patent licensing revenues between the inventing researchers and their institutions. ${ }^{210}$

204. Wolk, supra note 166 , at 420.

205. See id.

206. Morag Peberdy \& Alain Strowel, Employee's Rights to Compensation for Inventions-A European Perspective, in PLC CROSS-BORder LiFE SCIENCES HANDBOOK 63, 63 (2009/10).

207. Kelly v. GE Healthcare Ltd., [2009] EWHC (Pat) 181 [207] (Eng.).

208. Peberdy \& Strowel, supra note 206, at 66.

209. Research Policies, UNIV. OF OXFORD, http://www.ox.ac.uk/admissions/graduate/applying-tooxford/university-policies/research-policies (last visited Nov. 26, 2014).

210. Bekendtgørelse af lov om opfindelser ved offentlige forskningsinstitutioner (Consolidation Act. No. 210 on Inventions at Public Research Institutions), Mar. 17, 2009, § 12 (Den.); see also Siepmann, supra note 105, at 224. 
In France, for inventions within the scope of employment, an employee-inventor is entitled by statute to remuneration from one to three times the employee's monthly salary, although higher amounts have been awarded. ${ }^{211}$ For example, a court of first instance in Paris awarded a former employee of French National Railways (SNCF) more than \$750,000 for inventing a system that saved SNCF about $\$ 22$ million a year. ${ }^{212}$ In another French case, the French Supreme Court awarded an employee "additional remuneration" of $\$ 830,000$ for the transfer of intellectual property rights in a prostate cancer drug to Hoechst Marion Roussel, Inc. ${ }^{213}$

In Germany, the compensation for employees in the private sector is between ten percent and twenty percent of the economic value of the invention. $^{214}$ But different rules apply to the public sector. For example, university inventors receive thirty percent of the revenues generated from "commercialization" of the invention, ${ }^{215}$ as do researchers at the Max Planck Society, ${ }^{216}$ a public research organization whose scientists were never afforded the "professor's privilege." 217

\section{University Technology Transfer Offices}

A number of universities in the EU have established technology transfer offices to work with researchers and for-profit firms to commercialize inventions created in university laboratories. Such offices often license patents to for-profit firms. However, an Organisation for Economic Co-operation and Development (OECD) report ${ }^{218}$ revealed wide diversity in the structure and organization of technology transfer offices within and across the Member States. Variations include on- or off-campus offices, arm's length intermediaries, industry sector-based technology transfer offices, and regional technology transfer offices. ${ }^{219}$ The European Technology Transfer Offices circle comprises leading European public research organizations that have joined forces "to boost innovation in Europe through a set of initiatives, including fostering the use of their knowledge portfolio; sharing best practices, knowledge and expertise; performing joint activities; establishing informal channels of

\footnotetext{
211. Peberdy \& Strowel, supra note 206, at 65.

212. Id. at 63 .

213. Id. at 66 .

214. Id. at 65 .

215. Id. at 68 .

216. Buenstorf \& Geissler, supra note 16, at 485 .

217. Id. at 482 .

218. See generally ORG. FOR ECON. CO-OPERATION \& DEVEL., TURNING SCIENCE INTO BUSINESS: PATENTing AND Licensing AT Public Research ORganisations (2003).

219. Id. at 12 .
} 
communication with policymakers; organising training programmes; and developing a common approach towards international standards for the professionalisation of Technology Transfer."220

The majority of European university technology transfer offices appear to have on-site institutions integrated into the university or research institution. For example, Sorbonne University collaborates through strategic alliances with industry, and it files approximately twenty patents each year. Its intellectual property portfolio, which includes approximately 450 patents and other sources, generates more than one million euros annually in license fees. ${ }^{221}$ The Sorbonne encourages the creation of spinoff companies by professors and students and has established a complete range of independent structures to facilitate its technology transfer activities. For example, Université Pierre et Marie Curie, one of the Sorbonne's constituent universities,

partners with the government ministry, research organizations, private companies, foundations, associations, and laboratories. Research cooperation agreements have been set up with leading industrial groups through the Research and Technology Transfer Department. This department implements the University's science policy, monitors the activities of research and technology transfer, and supports University research organizations. 222

Humboldt University of Berlin's policy expressly notes the importance of securing patent rights for university inventions:

Safeguarding the rights to inventions is imperative for effective marketing. HU aims to ensure that university inventions with the potential for wider use are legally protected. Its patent policy places equal importance on the bundling of rights and the equal treatment of all University members. HU supports the academic quality of its research findings by providing optimised patent protection. It also makes the general public aware of the quality of its work by filing its own patent applications. $^{223}$

220. European Technology Transfer Offices Circle, EuropeAn COMM'N (Apr. 30, 2014), https://ec.europa.eu/jrc/en/tto-circle.

221. Pierre \& Marie Curie Univ., Creating the Future With Sorbonne University 14 (2013), http://www.upmc.fr/modules/resources/download/default/espace_personnels/communication/ Communiquer_en_anglais/creating-the-future.pdf.

222. Id.

223. Knowledge and Technology Transfer, HUMBOLDT-UNIVERSITÄT ZU BERLIN (Aug. 12, 2015), https://www.hu-berlin.de/en/research/transfer/ueberblick. 
The Max Planck Society created a separate subsidiary, Max Planck Innovation $\mathrm{GmbH}$, in 1970 to patent inventions, license them to domestic and foreign firms, and provide support for spin-offs. ${ }^{224}$ Max Planck Innovation applies for patents "if the invention is patentable and considered sufficiently promising, even if no licensee for the technology has been identified yet." 225

When the University of Copenhagen and certain other universities ${ }^{226}$ in Denmark collaborate with industry, they often insist that the university be the legal entity that enters into any agreements with external parties. As a result, external partners may not negotiate directly with individual researchers, faculties, or departments. Instead, all contracts must be negotiated through the University's Tech Transfer Office. In all its agreements, the University of Copenhagen seeks to advance the mission of creating and disseminating knowledge by requiring provisions permitting its researchers to publish their research results and to use them for research purposes. In addition, as discussed further below, the University must observe the EU State aid rules. As a result, neither favorable - that is, nonmarket-agreements with specific private companies nor the use of public funds to favor particular private companies is allowed. ${ }^{227}$

224. Buenstorf \& Geissler, supra note 16 , at 485.

225. Id.

226. Other Danish universities that collaborate with industry include, for example, Technical University of Denmark, Aarhus University, and Aalborg University. MINISTRY OF FOREIGN AFFAIRS OF Den., Start With DenMark: The HeART of LifE SCIENCES FOR ReSEARCH AND Business 39-40 (2013), http://www.investindk.com/ /media/Files/Sheets/Life\%20Sciences/StartWithDenmark_49pp_ LOW.ashx. The Inventor's Guide to Technology Transfer at Aarhus University states: "According to the Act on inventions at public research institutions, any inventions made by an employee as part of his or her work at a university under the Danish Ministry of Research and Information Technology belongs to the institution" and the technology transfer office negotiates licensing agreements "on behalf of the university"; the agreements "seek to provide a reasonable return to Aarhus University." AARHUS UNIVERSITET, INVENTOR'S GUIDE TO TECHNOLOGY TRANSFER AT AARHUS UNIVERSITY 13, 18-19 (2009), http://to.au.dk/fileadmin/www.tto.au.dk/Dokumenter/inventorsguide.pdf. The technology transfer information site for researchers at Aalborg University provides that Aalborg University "as an employer" has "the right to acquire all rights to that which the employee has invented in relation" to his or her work, and if the technology transfer offices determines the university should acquire the rights to the invention, the university will pay patent costs. An inventor may initiate the commercialization process himself or herself only when the university does not want to acquire rights to the invention. Technology Transfer - Rights and Obligations, AALBORG UNIV., http://www.en.patent.aau.dk/rightsobligations/ (last visited Nov. 25, 2015).

227. UNIV. OF COPENHAGEN, RESEARCH \& INNOVATION: COLLABORATING WITH THE UNIVERSITY OF COPENHAgEN - THE UNIVERSITY's OVERALL PRINCIPLES, 4 (2012), http://fi.ku.dk/english/box/pixi eng/KU_s_guide_vedr_samarbejdsaftaler_GB_tileksterntweb.pdf/. 


\section{Recent Changes to the EU Patenting Regime}

Academic entrepreneurship in the EU has been hampered by the high cost of securing patents in the EU. Figures from 2009 showed that it cost a minimum of fifteen times more to patent an invention in each of the twenty-seven EU Member States ${ }^{228}$ than in the United States. ${ }^{229}$ The high cost, which the European Commission called "a tax on innovation," is largely attributable to legal and translation fees. ${ }^{230}$

The EU has recently taken a variety of steps to create a faster, cheaper patenting system. In 2012, all the Member States except Poland, Spain, and Croatia agreed to facilitate uniform patent protection in the EU by adopting the Agreement on a Unified Patent Court. ${ }^{231}$ The Agreement will establish a Unified Patent Court ("UPC") with exclusive and specialized jurisdiction over patent cases in all the Member States except Spain, Poland, and Croatia, but the Agreement will not go into effect until at least thirteen Member States, including France, Germany, and the U.K., ratify it. ${ }^{232}$ As of September 2015, only Austria, Belgium, Denmark, France, Luxembourg, Malta, Portugal, and Sweden had ratified the Agreement. ${ }^{233}$ Also in 2012, the EU adopted two related regulations. The first created the Unitary Patent ("UP"), a patent based on uniform EU standards that will provide protection in all the Member States except Spain and Croatia. ${ }^{234}$ The second established a translation regime for UPs, ${ }^{235}$ which is expected to reduce the translation costs of obtaining a patent from approximately

228. As of June 2015 there were twenty-eight Member States. EU Member Countries, EUROPEAN UNION, http://europa.eu/about-eu/countries/member-countries/ (last visited Nov. 29, 2015).

229. Europe 2020 Flagship Initiative, supra note 12, at 15.

230. Id.

231. Council Notice 175/01, Agreement on a Unified Patent Court, 2013 O.J. (C 175) [hereinafter Agreement on a Unified Patent Court]; EC Taking Stock 2014, supra note 8, at 39.

232. EC Taking Stock 2014, supra note 8, at 39; Agreement on a Unified Patent Court, supra note 231, art. 84. Croatia has the option of adopting the two regulations and joining the UPC at a later time. Id. See also Council Regulation 542/2014, Amending Regulation 12/15/2012 as Regards the Rules to be Applied with Respect to the Unified Patent Court and the Benelux Court of Justice, 2014 O.J. (L 163). This Regulation shall apply from January 10, 2015.

233. Agreement Ratification Details, EuR. COUNCIL-COUNCIL OF THE EuR. UnION, http:// www.consilium.europa.eu/en/documents-publications/agreements-conventions/agreement/?aid= 2013001 (last visited Sept. 2, 2015).

234. Council Regulation 1257/2012, Implementing Enhanced Cooperation in the Area of the Creation of Unitary Patent Protection, 2012 O.J. (L 361). This Regulation is effective from January 1, 2014, or the date of entry into force of the Agreement on a Unified Patent Court, whichever is the later. Id.

235. Id. In accordance with article 7, this Regulation shall apply from January 1, 2014, or the date of entry into force of the Agreement on a Unified Patent Court, whichever is the later. This Regulation shall be binding in its entirety and directly applicable in the participating Member States in accordance with the Treaties. 
$€ 23,000$ to $€ 700$, saving innovative businesses approximately $€ 250$ million a year. ${ }^{236}$ Spain and Croatia had not implemented these two regulations as of October 2015. Thus, once the UPC Agreement goes into effect, it will be possible to obtain an EU patent based on unitary standards in one step.

The EU is also exploring ways to commercialize unused patented technology by forming a market mechanism for its valuation and transfer. ${ }^{237}$ "Technology markets tend to be thin; a few potential licensees typically exist for a particular technology and licensing is based on smallnumbers bargaining." ${ }^{238}$ Institutions of higher learning and businesses started forming Knowledge Alliances in 2014. ${ }^{239}$ These structured partnerships strive to "design and deliver new curricula and courses, to develop new and innovative ways of teaching and learning, to facilitate the flow of knowledge between higher education and companies, to stimulate interdisciplinary activities/learning and to develop entrepreneurial skills and attitudes." 240 The "ultimate goal" of Knowledge Alliances is to stimulate innovation in and through higher education and to make cooperation between higher education and business a "more common feature" of the higher education system in the EU. ${ }^{241}$

What may prove more challenging is providing the strong IP protection necessary to promote commercialization while respecting the EU's longstanding commitment to the public dissemination of publicly funded research. ${ }^{242}$ The European Commission asserted in 2014:

The basis for the development of a more efficient knowledge system that protects intellectual property and investments in knowledge while providing the conditions for open collaboration and knowledge sharing are in place. This concerns in particular the Unitary Patent, the exploration of knowledge markets for pa-tents and licences, and the transition from ... the concept of knowledge transfer to a system based on co-creation and open innovation. ${ }^{243}$

236. Press Release, European Comm'n, supra note 2.

237. See Towards Enhanced Patent Valorisation for Growth and Jobs, SWD (2012) 458 final (Dec. 21, 2012).

238. Buenstorf \& Geissler, supra note 16 , at 488 .

239. EC Taking Stock 2014, supra note 8, at 18, 90.

240. Id. at 18 .

241. Id.

242. Europe 2020 Flagship Initiative, supra note 12, at 19 ("The Commission will promote open access to the results of publicly funded research.").

243. EC Taking Stock 2014, supra note 8, at 34. See also EuROPEAn COllaborative \& Open REG'L INNOVATION STRATEGIES (EURIS), EMBRACING OPEN INNOVATION IN EUROPE: A BeST PRACTICES GUIDE ON OPEN INNOVATION POLICIES 11 (2012), http://cars.region-stuttgart.de/sixcms/ media.php/923/euris_guide.pdf [hereinafter EURIS] (explaining that "Open Innovation is the practice 
The Commission noted that while there has been "gradual yet visible progress" by most Member States in "putting strategies in place regarding access and dissemination of scientific information... their approaches vary considerably," with several Member States choosing "soft law rather than hard law when implementing [open access]."244

One organization promoting open access is Top Institute Pharma ("TI Pharma"), a self-described "independent research enabler of drug discovery and development" based in the Netherlands.

[TI Pharma] sets up and runs multidisciplinary partnerships that advance the development of socially valuable medicines. It links precompetitive, pharmaceutical research and expertise-from science to industry, from the Netherlands and across the globe-in open innovation. TI Pharma provides the third-party governance to build and safeguard the trust necessary in pharmaceutical partnership. ${ }^{245}$

Like the European Commission, TI Pharma asserts that "[o]pen innovation is the way forward-multidisciplinary collaboration between many different stakeholders in pursuit of groundbreaking research. But open innovation needs an independent third party that can bring partners together -driving R\&D towards the medicines we critically need." ${ }^{246} \mathrm{TI}$ Pharma's partners include small- and medium-sized enterprises, academia and knowledge institutes, large industry, and health foundations and patient organizations, as well as regulatory authorities and governments. ${ }^{247}$

Open innovation or access is, however, a double-edged sword. It encourages multidisciplinary and multi-party collaboration, but it also increases transaction costs and makes coordination far more difficult than it is in a partnership between one pharmaceutical firm and one or more research universities. Intermediaries like TI Pharma can help ameliorate these costs but cannot eliminate them. Open innovation also obscures the

of looking beyond the four walls of your company-towards suppliers, universities, producers of complementary products and services and other firms - to identify and capitalize on new opportunities for innovation").

244. EURIS, supra note 243, at 55.

245. Top Institute Pharma: The Independent Research Enabler, TI PHARMA, http://www.ti pharma.com/about-our-institute.html (last visited Dec. 1, 2014).

246. Vision, TI PHARMA, http://www.tipharma.com/about-our-institute/vision.html (last visited Dec. 1, 2014).

247. See Our Pharmaceutical Research Partners, TI PHARMA, http://www.tipharma.com/ partners.html (last visited Dec. 1, 2014) (including partners, for example, Vertex Pharmaceuticals Inc., Erasmus Medical Center Rotterdam, Drugs for Neglected Diseases Initiative (DNDI), AstraZeneca, the Medicines Evaluation Board, and the Netherlands Vaccine Institute). 
identity of the owner of the inventions created by such consortia. In the case of drugs for neglected diseases that cannot be sold at a profit, the pharmaceutical companies may be willing to donate their discoveries for the common good. But once a drug has demonstrated profit potential, the firms that contributed to its development will expect to share in the profits. As the Business for Social Responsibility's Healthcare Working Group (whose founding members include the heads of GlaxoSmithKline, Johnson \& Johnson, Merck, Novartis, and Takeda) stated:

We depend on $R \& D$ to promote innovation and we support a variety of approaches such as clear patent policies and, when appropriate, voluntary licensing and collaborative models to increase access to our products. We believe that appropriate intellectual property protection enables innovation and creates the necessary conditions to make our R\&D sustainable and enhance innovations over time. ${ }^{248}$

\section{Comparative Data on Academic Patenting in the United States and Europe}

Francesco Lissoni defines an "academic patent" as "any patent signed at least by one academic scientist, while working at his or her university." ${ }^{249}$ According to the Worldwide Patent Statistical Database maintained by the European Patent Office, ${ }^{250}$ academic patenting in Europe is most concentrated in the field of Pharmaceuticals and Biology, which includes cosmetics. ${ }^{251}$ This "reflects the important role of public science in scientific disciplines related to these technologies, and the close relationship between scientific discoveries and inventions therein," both in Europe and the United States. ${ }^{252}$

In the United States, universities own $68.7 \%$ of academic patents, companies own $24.2 \%$, individual scientists own $5.3 \%$, and the government owns $1.7 \%{ }^{253}$ In contrast, companies own most academic patents in many parts of Europe: $66.5 \%$ in Denmark, $61.4 \%$ in France, $72 \%$ in Italy, $60.5 \%$

248. Bus. fOr Soc. Responsibility HeAlthCARE Working GrP., Guiding PRinciples on ACCESS TO HEALTHCARE 3 (2013), http://www.bsr.org/pdfs/our-work/working-groups/BSR_HCWG_ GPAH.pdf.

249. Francesco Lissoni, Academic Patenting in Europe: An Overview of Recent Research and New Perspectives, 34 WORLD PATENT INFO. 197, 198 (2012).

250. See generally EPO Worldwide Patent Statistical Database (PATSTAT), EUROPEAN PATENT OFFICE, http://www.epo.org/searching/subscription/raw/product-14-24.html (last visited Oct. 29, 2015).

251. Lissoni, supra note 249, at 199.

252. Id.

253. Id. at 201 (compiling data from 1994 to 2002). 
in the Netherlands, $81.1 \%$ in Sweden, and $67.1 \%$ in the United Kingdom. ${ }^{254}$ As a result, if one counts only patents owned by universities, it would appear that "European academic science does not contribute to technological advancements or, more prosaically, that it does not patent enough. $" 255$ As seen in Table 3, this disparity is reduced or eliminated entirely when one compares not only the number of university-owned patents in the United States with those owned by universities in Europe (which increased from 390 in 1998 to 936 in $2004^{256}$ ), but also compares all academic patents in both regions, regardless of whether they are owned by universities, individual scientists, or the government. ${ }^{257}$

\section{Table 3}

\begin{tabular}{|l|l|l|}
\hline Country & $\begin{array}{l}\text { Percentage of Total } \\
\text { Domestic Patents Owned } \\
\text { by Universities }\end{array}$ & $\begin{array}{l}\text { Academic Patents as } \\
\text { a Percentage of Total } \\
\text { Domestic Patents }\end{array}$ \\
\hline United States & 4.0 & 6.0 \\
\hline France & 0.3 & 3.4 \\
\hline Italy & 0.4 & 4.0 \\
\hline Netherlands & 1.0 & 4.3 \\
\hline Sweden & 0.3 & 6.2 \\
\hline
\end{tabular}

Source: Francesco Lissoni, Academic Patenting in Europe: An Overview of Recent Research and New Perspectives, 34 WoRLD PATENT INFO. 197, 201, fig. 3 (2012).

254. Id. at 200-01. ("[T] the type of ownership of academic inventions (which may have a consequence for whether these inventions are eventually marketed), is affected by at least three phenomena: the national IP legislation with respect to academic inventions; the division of labour between public research organizations and the universities in the science system; and the characteristics of universities in terms of autonomy and expertise in self-administration.").

255. Id. at 197.

256. Manuel Acosta et al., Production of University Technological Knowledge in European Regions: Evidence from Patent Data, 43 REGIONAL STUD. 1167, 1172 (2009); see also id. at 1173 (showing pharmaceuticals accounted for $39.15 \%$ of the 4,580 university-owned European patents granted in the period from 1998 to 2004. The regions with the largest number of pharmaceutical patents were Inner London, U.K. (11.2\%), Berkshire, Buckinghamshire and Oxfordshire, U.K. (6.9\%), Vlaams Gewest, Belgium (5.1\%), Zuid-Holland, the Netherlands (4.6\%), and Île de France, France (3.8\%)).

257. Because companies, not universities, own most academic patents in Europe, a calculation that compares university-owned patents in the United States with university-owned patents in Europe suggests that European academic scientists are not as productive in generating patentable discoveries. 
As Lissoni noted in 2012, "[v]ery heated political discussions have taken place over the past few years, about whether technology transfer detracts from basic research." 258 Citing multiple papers, he states: "Overwhelmingly, the evidence suggests that academic inventors are very highly productive scientists: a fixed effect exists, by which highly productive academic scientists are more likely than less productive ones to turn into inventors and, conversely, academic inventors exhibit higherthan-average scientific productivity."259 Similarly, Rosa Grimaldi et al. report: "Academic research has found little systematic evidence of a destruction of the open culture of science or to support the assertion that universities are performing less basic research." ${ }^{260}$ Instead, "the published evidence suggests that patenting is followed by an increase in scientific productivity." 261

Lissoni also cites what he characterizes as the "well-established result, at least for the U.S., . . . that university-owned academic patents appear to be more general and important than corporate ones, where importance is measured by the number of citations received, and generality by the number of technological classes from which the citations come." 262 The empirical evidence from Europe is more mixed. Based on their analysis of data from the European Patent Office, Emanuele Bacchiocchi and Fabio Montobbio found that patents by European and Japanese academic institutions and public research organizations were not cited more than average. ${ }^{263}$ But Dirk Czarnitzki, Katrik Hussinger and Cedric Schneider found that German academic patents were cited more than the average. ${ }^{264}$ Although European academic patents owned by individual inventors are cited less frequently than the average patent, "country specificities emerge, which can be explained by the different legal and institutional environments." 265 European academic patents, particularly those owned by universities, public research organizations and governments, are more

258. Id. at 202 .

259. Id.

260. Grimaldi et al., supra note 13, at 1046.

261. Lissoni, supra note 249, at 202.

262. Id. at 204.

263. Id. (citing E. Bacchiocchi \& F. Montobbio, Knowledge Diffusion from University and Public Research: A Comparison Between US, Japan and Europe Using Patent Citations, 34 J. TECH. TRANSFER 169, 179-80 (2009)).

264. Id. (citing Dirk Czarnitzki et al., Commercializing Academic Research: The Quality of Faculty Patenting, 20 INDUS. \& CORP. CHANGE 1403, 1423 (2011)).

265. Id. 
general than average. ${ }^{266}$ In addition, "[i]ndividually owned academic patents appear to be more original than average. ${ }^{267}$

\section{PUBLIC POLICY CONCERNS RAISED BY UNIVERSITY LICENSING IN THE UNITED STATES AND THE EUROPEAN UNION}

Public policy questions are raised when a university patents an invention funded by the government and then licenses it to a private entity. ${ }^{268}$ Overly broad licenses from academic institutions to private firms can stifle academic discovery and squelch innovation. For example, "reachback licenses," which give the private firm licensee the right to any followon innovations developed by the academic institution, are particularly burdensome because they limit researchers' ability to transfer new discoveries to other private firms that might offer better terms or be better equipped to commercialize the discoveries. Similarly, if the academic institution has no access to the discoveries the private firm makes when developing and commercializing the technology, this may hamper further work by the academic researchers.

While many universities have dedicated themselves "to the creation and dissemination of knowledge for the public good," ${ }^{269}$ the leadership of each university "must decide whether and to what extent to embrace commercially oriented activities" based upon the respective university's "mission." $" 270$ Certain universities, especially in the United States, "view technology transfer as indelibly linked with their social obligations as universities." ${ }^{271}$ But because "[u]niversities ... are not in the business of developing commercial technologies," some argue that the private sector is better suited to commercializing academic inventions. ${ }^{272}$ Technology transfer can be the link between publicly sponsored research and privatesector commercialization. ${ }^{273}$ For example, the mission of M.I.T.'s Technology Licensing Office "is to foster commercial investment in the development of inventions and discoveries flowing from the research at the

266. Id.

267. Id.

268. See generally Jacob H. Rooksby, Myriad Choices: University Patents Under the Sun, 42 J.L. \& EDUC. 313 (2013).

269. Sara E. Crager et al., University Contributions to the HPV Vaccine and Implications for Access to Vaccines in Developing Countries: Addressing Materials and Know-How in University Technology Transfer Policy, 35 AM. J.L. \& MED. 253, 258 (2009).

270. Peter Lee, Transcending the Tacit Dimension: Patents, Relationships, and Organizational Integration in Technology Transfer, 100 CALIF. L. REV. 1503, 1566 (2012).

271. Id.

272. Id. at 1506

273. Id. 
Massachusetts Institute of Technology and Lincoln Laboratory."274 M.I.T. asserts that "[i]t is through these investments - and the economic development and new products that follow from them-that university technology provides direct benefits to the public." 275

But close ties between academic researchers and industry can create conflicts of interest, ${ }^{276}$ result in perverse incentives, ${ }^{277}$ and force a shift from basic to applied research. ${ }^{278}$ In addition to interfering with the creation and transfer of knowledge, licenses to private firms can deprive patients of life-saving therapies. "[S]trong resentment and frustration have emerged as a result of the licensing and patent policies of universities," particularly when universities grant exclusive licenses to firms that "restrict access to essential products in the developing world. ${ }^{, 279}$ Because many licenses give

274. MIT Technology Licensing Office, MASs. Inst. OF TECH. TECH. LiCEnsing Office, http://web.mit.edu/tlo/www/ (last visited Dec. 1, 2014).

275. Mass. Inst. OF Tech., An InVEntor's Guide to TeChNOlOgy TRANSFER AT the MASSACHUSETTS InSTITUTE OF TECHNOLOGY (2005), http://tlo.mit.edu/sites/default/files/documents/ MITInventGd V5\%204-7-2010.pdf.

276. See generally Bryan A. Liang \& Tim Mackey, Confronting Conflict: Addressing Institutional Conflicts of Interest in Academic Medical Centers, 36 AM. J.L. \& MED. 136 (2010). See also M.I.T. POLICIES, supra note $125, \S 4.10 .2$ (explaining that to help ameliorate the conflicts involved when an inventor will hold equity or options in a closely held company to which a university invention will be licensed, M.I.T. requires prior approval from the Vice President for Research before it will accept equity in lieu of cash royalties. Similarly, if the inventor will continue as an M.I.T. employee after receiving equity in the licensee, the employee must sign M.I.T.'s Conflict Avoidance Statement.); Katie Thomas, Using Doctors With Troubled Pasts to Market a Painkiller, N.Y. Times, Nov. 27, 2014, at A1 (noting that conflicts of interest also arise between industry (i.e., pharmaceutical companies) and doctors when pharmaceutical companies pay doctors for "speaking fees, travel and meals" to promote their products. This can result in a doctor "inappropriately prescribing" a drug company's products, and it has been reported that some drug companies, in their quest to "cultivate relationships" with doctors, seek doctors with "troubled track records to market" their products to other doctors. "[D]rug companies have paid billions of dollars" in the past few years to "settle federal charges that they inappropriately marketed their products, sometimes by providing 'speaking fees' in exchange for the doctor's prescribing behavior.” Eric C. Campbell, a Harvard Medical School Professor of Medicine who studies these conflicts of interests, said that "[t]his appears to be the business plan. . . It appears to be, you do whatever you have to do, and you know that eventually you will pay fines, but you will pay the fines and still make a lot more").

277. Liang \& Mackey, supra note 276, at 156 (noting that "the [academic medical center] can be seen as an actor interested in research that can result in patent exclusivity, which in the drug development context results in higher costs of pharmaceuticals, with a focus on prioritizing projects with immediate marketability ... [which] undermines the basic tenet of the [academic medical center], and the physicians and researchers who work within it, to benefit the public good first").

278. Id. (noting that "[s]ome have argued that the [lucrative revenue streams produced by these arrangements] have led [academic medical centers] to shift away from their primary goal of unfettered scientific research, to focus on industry-oriented research and technology transfer incentives, which has transformed them into corporate research laboratories, dampening the progression of discovery").

279. Hafiz Aziz ur Rehman, Equitable Licensing and Publicly Funded Research: A Working Model for India?, 16 Sw. J. INT’L L. 75, 88 (2010). 
pharmaceutical firms the right to decide where to file patents, the companies "generally file strategic patents in many developing countries to minimize the risk of competition from generic drugs." 280

In response to push-back from a coalition that included the inventor of the HIV drug Zerit ${ }^{\circledR}$ the former head of the WHO's HIV/AIDS program and 600 Yale University professors, researchers, and students who signed a petition calling on the university to "ease its patent" on Zerit $\AA$, Yale persuaded its exclusive licensee Bristol-Myers Squibb to enter into an "agreement not to sue" with Aspen Pharmacare, the leading generic manufacturer in South Africa. As a result, Aspen was able sell the drug in South Africa at a fraction of the price charged in developed countries. ${ }^{281}$

Notwithstanding their proud history of creating and disseminating knowledge to the public, research universities in the EU and regulators may have to choose between open access and commercialization, at least for certain downstream discoveries. Of course, this is not a binary choice. As argued below, open access may be suitable for upstream research data and research tools developed in the university laboratory, but not for downstream applications of that data or those tools. Indeed, the Union-wide Pilot on Open Research Data in Horizon 2020 recognizes these tradeoffs by giving parties the ability to opt out "under defined circumstances, including conflict with obligations to protect results, with confidentiality obligations, with security obligations or with rules on protection of personal data. Parties may also opt out if the achievement of the action's main objective would be jeopardised by making specific parts of the research data openly accessible." ${ }^{282}$ Thus, if the success of a PPPP required keeping research data confidential, that would appear to be permissible.

The public policy issues are particularly acute when a university issues an exclusive license on a foundational technology or research tool

280. Id.

281. Stevens \& Effort, supra note 172, at 87; see also id. at 98 (explaining that Universities Allied for Essential Medicines, a student organization that grew out of Amy Kapczynski's work at Yale with Zerit $^{\circledR}$, "convened" an independent working group that developed the Equitable Access License, which is designed to promote the use of university inventions to promote global health by providing "a mandatory grantback of all improvements made by the primary licensee to the academic institution, which can then license the complete package of intellectual property non-exclusively to third parties who wished to make and sell the products in developing countries." In exchange, the university would charge a 5\% royalty on sales in Middle Income Countries and a 2\% royalty for sales in Low Income Countries (as defined by the World Bank) and then split the royalties with the primary licensee. The pharmaceutical firms with which they discussed this matter indicated that they would be unwilling to license academic inventions pursuant to a license that gave the university a grantback of the inventions the private firms generated in the course of developing and commercializing the licensed technology. Thus, this approach is unlikely to work for the development of for-profit drugs).

282. EC Taking Stock 2014, supra note 8, at 55. 
funded by the government to a private for-profit pharmaceutical enterprise. For example, Harvard University was criticized for granting the DuPont Pharmaceutical Company exclusive rights to the "oncomouse," a strain of transgenic mice created with "a proprietary gene-insertion method called Cre-loxP, which enables a researcher to select particular conditions under which expression of a transgene may be induced or repressed." ${ }^{283}$ DuPont demanded that scientists stop sharing data generated by research using the mice, submit future scientific journal articles to DuPont for pre-publication review, and give DuPont "'reach-through' rights to downstream inventions arising from the use of transgenic animals created by the Cre-loxP method." 284 The director of the NIH and others successfully pressured DuPont to relax its restrictions on the use of its transgenic animals and to stop demanding reach-through rights and pre-publication review of research. $^{285}$

Certain universities "have recognized the impact they can have on improving access to medicines that originate on their campuses" and view themselves as "ideally suited to address the dire needs of the estimated 10 million people who die each year because they do not have access to existing medicines and vaccines." 286 For this reason, universities may be willing to forgo some or all license and royalty fee revenue, especially when the invention relates to a disease prevalent in developing countries, such as malaria or tuberculosis. But other universities have sought to maximize the royalty streams available from their research. Particularly at a time when available federal grants from the NIH and other funders have been sharply reduced, royalty income may be seen as necessary to fund further research or other needs, including financial aid for needy students.

To address concerns about access to life-saving drugs, a group of U.S. universities promulgated a statement of "Nine Points to Consider" when patenting or licensing pharmaceutical inventions. ${ }^{287}$ That guidance explains that universities should structure licensing agreements in a manner that

283. Hoffman, supra note 107, at 1029; see also Edward Lee, The New Canon: Using or Misusing Foreign Law to Decide Domestic Intellectual Property Claims, 46 HARV. INT'L L.J. 1, 4-5 (2005) (noting that the Supreme Court of Canada held that the oncomouse was not patentable subject matter because it was a "higher life form," not an article of "manufacture" or "composition of matter" even though the United States, Japan, and the EU had granted Harvard University patents for the transgenic mouse).

284. Hoffman, supra note 107 , at 1029.

285. Id. at 1029-30.

286. Crager et al., supra note 269, at 258.

287. See generally CAL. Inst. of TeCh. ET AL., In the Public Interest: Nine Points to CONSIDER IN LICENSING UNIVERSITY TECHNOLOGY (2007), www.otl.stanford.edu/documents/white paper-10.pdf. 
gives "underprivileged populations," especially those in developing countries, no-cost or low-cost access to pharmaceutical innovations. ${ }^{288}$ Alternatively, a university may try to license its invention only to a pharmaceutical enterprise with similar humanitarian views, under a concept termed "socially responsible licensing." 289 Or, a university or private firm may seek an NGO (non-governmental organization), such as the Bill and Melinda Gates Foundation, ${ }^{290}$ to pay a fair royalty or licensing fee for drugs for patients in developing countries and neglected diseases.

The NIH has adopted protocols offering guidance on when it is appropriate for a research university to patent certain innovations. ${ }^{291}$ Although it lacks clear legal authority to do so, the NIH has conditioned grants on an applicant's willingness to forgo seeking broad patents on the human genome. As discussed further below, we encourage Congress to expressly grant the NIH such power.

Certain academics argue that exclusive patent licenses are necessary to reduce "the perceived risk of investing in unproven technology to attract private risk capital." ${ }^{\prime 292}$ But former Harvard University President Derek Bok cautioned that "[z]ealous campus officials can slow commercial applications and drive up prices of valuable products by granting exclusive patent licenses, where nonexclusive licenses would be feasible, merely to let the university share in any monopoly profits that the exclusive licensee manages to earn. ${ }^{293}$ Patent pools, which are discussed in Part VI.B., can help address this issue.

288. Crager et al., supra note 269 , at 258-59.

289. Rehman, supra note 279 , at $88-89$.

290. See Stevens \& Effort, supra note 172, at 92-93.

291. See Best Practices for the Licensing of Genomic Inventions: Final Notice, 70 Fed. Reg. 18,413 (Apr. 11, 2005); Principles and Guidelines for Recipients of NIH Research Grants and Contracts on Obtaining and Disseminating Biomedical Research Resources: Final Notice, 64 Fed. Reg. 72,090 (Dec. 23, 1999).

292. Lori Pressman et al., The Licensing of DNA Patents by Large US Academic Institutions: An Empirical Survey, 24 NATURE BioteCH. 31, 37 (2006).

293. DeREK C. BOK, Universities IN THE MARKetPlace: The COMMERCIALIZATION OF Higher EDUCATION 112 (2003). See Rebecca Goulding et al., Alternative Intellectual Property for Genomics and the Activity of Technology Transfer Offices: Emerging Directions in Research, 16 B.U. J. SCI. \& TECH. L. 194, 195 (2010) (discussing how technology transfer offices are traditionally evaluated and suggestions of new metrics that "could influence the adoption of alternative IP approaches and better evaluate the contribution of genomic research to society"). 


\section{CREATING A NEW TECHNOLOGY TRANSFER MODEL FOR THE EUROPEAN UNION}

Although the Bayh-Dole Act was initially characterized as “innovation's golden goose," ${ }^{294}$ individuals and organizations later questioned the influence it actually had on university research. ${ }^{295}$ There are significant advantages to the U.S. approach to commercializing government-funded inventions, but we submit that the EU should not enact legislation akin to Bayh-Dole without giving universities and public funders more discretion regarding (1) when technology must be patented to avoid having it revert to the government, (2) who owns the patents, and (3) when exclusive licenses are permissible.

We agree with Liza Vertinsky that "[u]niversities should... be viewed not simply as 'engines,' but rather as guardians of their inventions, and the law should be designed to encourage their responsible involvement in shaping the post-discovery future of their wards." 296 This would create a middle ground between the model of open innovation in the IMI and open access in Horizon 2020 on the one hand, and the "anticommons" created by the current U.S. system on the other.

Lissoni's research makes clear that the research university does not necessarily have to own the IP created by its researchers for commercialization to occur. ${ }^{297}$ The EU should, however, act to promote the clear and economically efficient allocation of IP rights to governmentfunded academic inventions among the governments providing the funding, the private pharmaceutical entities, the public universities, and the academic and industrial researchers engaged in PPPPs and other publicprivate collaborations. ${ }^{298}$ The divergent national rules in the Member States concerning both the ownership of the IP rights stemming from university research and the rights of the individual researchers to a share of the royalties generated by their discoveries make it harder and more expensive

294. Innovation's Golden Goose, ECONOMIST, Dec. 12, 2002, available at http://www.eco nomist.com /node/1476653.

295. See, e.g., Bayhing for Blood or Doling out Cash?, ECONOMIST (Dec. 20, 2005), http:// www.economist.com/node/5327661.

296. Liza Vertinsky, Universities as Guardians of Their Inventions, 4 UTAH L. REV. 1949, 1949 (2012).

297. See generally Lissoni, supra note 249.

298. See Bart Verspagen, University Research, Intellectual Property Rights and European Innovation Systems, 20 J. ECON. SURVEYs 607, 618-20 (2006) (explaining that maximizing the likelihood and magnitude of success of a PPPP or other joint research project requires the parties to decide who should own the patents resulting from university research - the government, the university, or the individual researcher). 
for public and private parties to negotiate and operate efficient PPPPs. The European Commission could enhance transparency, reduce transaction costs, and promote efficiency by encouraging at least some harmonization of the Member States' laws regarding the ownership of inventions while permitting the Member States to choose from a menu of options. We also urge the EU to require universities to share at least some of the royalties and fees they receive from discoveries funded by public money with the individual researchers, or to provide non-financial incentives, such as reduced teaching loads, more graduate students, or better equipped laboratory space. Finally, we applaud recent steps taken to clarify the application of the State aid rules to PPPPs, discussed in Part VI.C, and suggest additional safe harbors in Part VI.B.

\section{A. Ensuring a Clear and Efficient Allocation of Intellectual Property Rights}

\section{Harmonization with Flexibility}

The opaque patchwork of national laws allocating IP rights to governments or universities and their researchers in the EU impedes efficient technology transfer. Clear rules would facilitate the transfer of technology from the university research lab to the marketplace, both by clarifying ownership of inventions and by offering incentives for researchers to collaborate with industry. We assert that the European Commission should, as part of its overall restructuring of patent law in the EU and in furtherance of the Innovation Union, make harmonization and the creation of appropriate incentives a priority.

Even though achieving Union-wide consensus on the ownership of intellectual property will not be easy, we believe that it may not be as difficult as it first appears. In practice, by operation of law or pursuant to contract, most of the Member States already give an employer the rights to an invention created by one of its employees if the invention was created in the course of the employee's normal duties and the invention might reasonably have been expected to result from carrying out such duties. ${ }^{299}$ The European Commission could clarify ownership rights by establishing a default rule to this effect, which would apply unless a Member State enacted legislation, taken from a limited menu of options, that clearly articulates who owns the discoveries generated by university researchers utilizing public funds. Thus, Italy and Sweden could elect to keep their current system-giving academic researchers all ownership rights to the

299. See supra note 171 and accompanying text. 
inventions - and the U.K. and Germany could maintain their practice of giving those rights to the universities unless the universities and their researchers agreed otherwise by contract. Rather than incurring the transaction costs associated with individual assignments of inventions, universities should consider adopting various templates, perhaps through the European Technology Transfer Offices circle. That way, researchers could factor a university's technology transfer rules into account when deciding where to work, thereby enhancing the efficiency of the labor markets in the EU.

Our proposal would permit the Member States to determine, perhaps university by university, the proper balance between a university's role in promoting the free flow of information and its need to both raise money to fund future research and to give private industry partners a financial incentive to commercialize promising discoveries. Thus, certain inventions, especially those funded exclusively with government money, might be public goods available to anyone; others could be proprietary to promote commercialization. Compare, for example, the University of Copenhagen technology transfer policy with the policy at the University of Oxford. On the one hand, the University of Copenhagen states that it "places great importance on its collaborative relations with external partners and... strive[s] to enter collaboration agreements as fast and as smoothly as possible. In this process, the University focuses more on the transfer of knowledge and less on financial return." ${ }^{300}$ Other institutions, including Oxford, focus more on financial return for the university and, in certain institutions, the researchers themselves. Oxford's policy states:

Oxford's approach to exploitation of IP includes a generous revenuesharing policy, which brings significant personal benefits to researchers, and a hugely successful and well-resourced technology transfer operation, Isis Innovation. Isis works with University researchers on identifying, protecting and marketing technologies through licensing, spin-out company formation, consulting and material sales. ${ }^{301}$

For the reasons set forth immediately below, we also encourage the EU to adopt a default rule providing that academic researchers and their research units (e.g., their departments) are entitled to receive specified percentages of the net revenues received by their university as a result of their inventions. The Member States (or, pursuant to legislation adopted by a Member State, the universities in that State) might be given a range

300. UNIV. OF COPENHAGEN, supra note 227, at 3.

301. Research Policies, supra note 209. 
within which they could increase or decrease those default percentages, depending upon their own societal values. At a minimum, each university should be required to specify the share of royalties (or at least the minimum percentage of royalties) payable to the academic inventors for licensed inventions and patents and the equity guaranteed an inventor in the case of a spin-off of university technology.

2. Understanding the Differing Utility Functions of Three Dyads in the EU

Ensuring an efficient allocation of IP rights requires that policy makers, universities, and private actors analyze the varying interests of three dyads involved in the funding and conduct of pharmaceutical research in the EU: (1) the EU and the Member State, (2) the Member State and the university or industrial firm, and (3) the university and its industrial partner and the research scientists. The EU funds partnership research among universities and the private pharmaceutical sector through Innovative Medicines Initiative ("IMI") grants. The Member States fund research at the university level, and universities, in turn, fund research scientists and their departments. Because the players have different utility functions, ${ }^{302}$ their disparate and joint interests must be taken into account when allocating IP rights by law or private contract.

\section{a. The EU and the Member State}

The EU's bold plans for an Innovation Union include the development of new healthcare technology and pharmaceutical products that will both make the EU more competitive in the global marketplace and provide better medical outcomes for individuals living in the Member States. The European Commission stated that collaboration between public universities and the private pharmaceutical sector is important to the success of the IMI, and it recommended greater use of PPPPs to achieve this objective. ${ }^{303}$

Aside from wanting to diversify the inputs for innovation and to allocate the rewards in a fair manner to ensure political, social, and

302. See Bagley \& Tvarnø, supra note 45, at 386-90, 396; Prajit K. DutTA, Strategies AND GAMES: THEORY AND PRACTICE 52-53 (1999).

303. See, e.g., European Commission Press Release MEMO/14/468, Public-Private Partnerships Under Horizon 2020: Launch of Activities and First Calls (July 9, 2014), http://europa.eu/rapid/pressrelease_MEMO-14-468_en.htm. With regard to IMI 2, Máire Geoghegan-Quinn, former European Commissioner for Research, Innovation and Science, said: "Close cooperation between public and private actors in the life science sectors can help us towards the goal [of providing better healthcare for Europeans]." Id. at 1. Roch Doliveux, the Chair of the IMI Governing Board, remarked: "With IMI 2, Europe reinforces its leading position and innovation public-private partnerships, engaging all of our brain power across academia and industry ...." Id. at 2 . 
economic stability, the EU should remain agnostic as to which Member State generates the next blockbuster drug. Rather than picking national champions, the EU should direct human and financial capital to those parties most likely to develop the most significant discoveries at the lowest cost. That is a basic premise of the IMI model, which seeks competing bids in response to calls for proposals.

The Member States compete with each other to garner the largest "IMI market share." If a given Member State's universities do not win the competition for limited public and private funding, the Member State will lose valuable opportunities to innovate, provide new jobs, and grow. In this respect, the interests of the EU and the Member States are similar and can be described as a growth agenda that can be accomplished through properly crafted PPPP contracts and the efficient allocation of IP rights. But the individual Member States might be tempted to "put a thumb on the scales" to give their own national firms the right to technology developed by their universities with public funds at lower-than-EU market rates. As long as the Member States can introduce national legislation that conflicts with the EU objectives, the future of PPPPs in the EU is problematic. This danger can be addressed through both the efficient allocation of intellectual property rights and the proper implementation of the State aid rules.

When crafting the rules allocating IP rights, it is critical for policy makers to keep in mind that the various participants in a PPPP may have different utility functions, which will determine which choices they deem rational. ${ }^{304}$ If a party's share of the returns from the IP resulting from a PPPP is too low, it might not collaborate and the contract will fail to meet the parties' objectives.

A French study compared traditional contracting schemes and licensing allocations with the terms of PPPPs ${ }^{305}$ based on the European public-private partnership initiative between European Federation of Pharmaceutical Industry and Associations ("EFPIA") and the European Commission (DG Research - health priority) that resulted in the IMI. The study was designed to establish a model for PPPPs that would promote growth and innovation through an alternative model of collaboration while, at the same time, ensuring a balance between academic and industry interests in discovering and developing innovative drugs for the benefit of all stakeholders, including consumers. ${ }^{306}$ The study concluded that the back

304. DUTTA, supra note 302, at 12.

305. Jacques Demotes-Mainard et al., Public-Private Partnership Models in France and in Europe, 61 THÉRAPIE 325, 326 (2006).

306. See Bagley \& Tvarnø, supra note 45 , at $400-01$. 
offices in both the public and the private sector must be educated about the aims and objectives involved in negotiating, signing, executing, operating, and finalizing a PPPP collaboration. In particular, the study found that establishing the basis for a common culture on project management and intellectual property and promoting trans-disciplinary profiles, requires:

training personnel (including not just researchers, but also public administrative staff) in project management to ensure fulfillment of contract objectives, adherence to timelines, quality assurance, and the on-time production of all deliverables;

mobility between the public and the private sector; and specialized training in translational medicine or pharmaceutical medicine covering target and drug discovery, preclinical develop-ment, clinical trials, and management. ${ }^{307}$

At a minimum, therefore, the European Commission should issue guidance to help ensure that the back offices of both the private and public parties to a PPPP understand the importance of allocating the IP rights efficiently in their IMI or other contracts. Given the importance of the IMI to the Innovation Union, the absence of such guidance in the IMI is particularly problematic. Because the allocation will affect the likelihood of success, we further recommend that bidders be required to include their proposed PPPP contract with their bid for IMI funds.

\section{b. The Member State and the University or Industrial Firm}

Each Member State should seek to foster closer collaboration between its academic institutions and industry participants to attract investment without either sacrificing the public good created by the academy and its members or violating local cultural norms. Public universities should be able to receive grants from the Member State to perform basic scientific research and, at the same time, collaborate with industrial firms to generate revenues that can be plowed back into the university to fund further research or meet other needs. But universities and pharmaceutical companies have different drivers and underlying motivations. As discussed above, private pharma-ceutical companies generally seek to maximize shareholder wealth, ${ }^{308}$ while universities focus primarily on research and

307. Demotes-Mainard et al., supra note 305, at 332.

308. George Merck, the pharmaceutical company's founder, had a different view. His son, George W. Merck, explained his father's vision of the company by stating: "We try to remember that medicine is for the patient. We try to never forget that medicine is for the people. It is not for the profits. The profits will follow and if we have remembered that, they have never failed to appear." SUSAN E. REED, 
the creation and dissemination of knowledge. Thus, the university must ensure that commercialization of its publicly funded science does not unduly restrict use of basic scientific discoveries. At the same time, it must offer sufficient incentives to persuade private firms to fund and commercialize academic discoveries.

The Member States should develop competencies and dynamic capabilities, including national PPPP platforms, to help industry participants and universities successfully respond to IMI calls. ${ }^{309}$ In order to enhance innovative competencies, both in academia and industry, the Member States must help develop knowledge networks and innovation clusters of the sort that gave birth to the Silicon Valley in the United States. They should also facilitate transparency and the sharing of information so that transactions are priced properly, build up national infrastructures (by funding basic research, for example, or providing scholarship funds for aspiring scientists), and promote knowledge management and education. Additionally, like the European Commission, the Member States should ensure that national applicants for IMI funds allocate the IP rights in the most efficient way.

c. The University and Its Industrial Partner and the Research Scientists

If structured properly, the relationships between a university and its industrial partners can provide unique competitive advantages at both the university and industry levels. ${ }^{310}$ Game theory can explain the interdependence among the contracting parties to a PPPP, ${ }^{311}$ as well as the parties affected by the PPPP, such as individual academic and industry researchers. It can also suggest the possible outcomes of various choices and, thereby, assist negotiators in better predicting how contractual provisions are likely to affect the strategy the other party might choose.

The efficient equilibrium for the allocation of IP rights depends, at least in part, on the ex ante bargaining power of the parties. "R\& $\mathrm{RD}$ expenditures [by a pharmaceutical firm] are strategic and rational if they are chosen to maximize the profit from developing a new drug," given the firm's inferences concerning "the competition's commitment to this line of

\footnotetext{
The Diversity Index: The Amazing Truth About Diversity in Corporate AmericA. . .And What CAN Be Done ABout IT 44 (2011).

309. See Demotes-Mainard et al., supra note 305, at 326.

310. See generally Verspagen, supra note 298 (discussing the literature on university patenting).

311. Bagley \& Tvarnø, supra note 45, at 386-90.

312. Philippe Aghion \& Jean Tirole, Opening the Black Box of Innovation, 38 EUR. ECON. REV. 701,704 (1994).
} 
drug." ${ }^{313}$ Ex ante, a university researcher is often unable, due to a lack of capital and know-how, to negotiate effectively with a private company for the transfer of ownership, even when such a transfer would create the highest total surplus. ${ }^{314}$ Thus, it can be argued that the university researcher should not hold the IP rights in the first place; instead, the IP rights would be more efficiently placed with the university, which holds more capital and has greater bargaining power ex ante. This is the economic foundation of Bayh-Dole.

But the utility attainable from a discovery is not always transferable in ex ante bargaining over IP rights between a university and a private pharmaceutical company. Without the academic's active involvement, most attempts to commercialize are far more likely to fail. ${ }^{315}$ In addition, the private ownership of patents by university researchers might lead to a situation in which the individual inventors (if they own the IP rights to their discoveries) can easily transfer them to the private industrial firms that have the capital and other resources to commercialize them. ${ }^{316}$ As Lissoni found, this already happens frequently in Europe. ${ }^{317}$ "Giving property rights to the research unit is optimal when it is more important to encourage the unit's effort to discover than to boost the customer's financial (and nonfinancial) investment in the research." 318 That reasoning underlies the professor's privilege. ${ }^{319}$

Research by a PPPP is usually conducted by researchers in both private companies and universities. The privately employed researcher is assumed to be appropriately compensated for acting as directed by the employer. So, absent shirking, the industrial researcher's objectives will be closely aligned with those of its employer. In contrast, the rewards and costs associated with discovery and commercialization for the academic

313. DuTTA, supra note 302, at 5.

314. Aghion \& Tirole, supra note 312 , at 707-08.

315. Reddi Kotha et al., Bridging the Mutual Knowledge Gap: Coordination and the Commercialization of University Science, 56 ACAD. MGMT. J. 498, 503 (2013) ("[A]t the time of license, most university inventions are at such an early stage of development that no one knows if they will eventually result in a commercially successful innovation or not. Moreover, they are so embryonic that further development with the active involvement of the inventor is required for any chance of commercialization." (emphasis added) (internal citation omitted)).

316. Verspagen, supra note 298, at 619.

317. See generally Lissoni, supra note 249 (discussing the extent of academic patenting in Denmark).

318. Philippe Aghion \& Jean Tirole, The Management of Innovation, 109 Q. J. ECON. 1185, 1186 (1994). Note that customers are defined as "those parties who directly benefit from the innovation; namely, the manufacturers who commercialize the innovation, the users who will purchase the resulting product, and the suppliers of complementary products." Id.

319. See supra text accompanying notes 170-82. 
researcher may differ from those of the employing university. Thus, when deciding how to allocate the financial rewards derived from university scientists' inventions, it is important for both public policy makers and individual institutions to consider academic researchers' utility function to ensure an appropriate pay-off.

Many academic researchers are driven less by purely monetary rewards like shared royalties than by a desire to create and disseminate knowledge, to improve their own academic research skills, to increase their research capacity, and to ensure their own advancement in the academy. ${ }^{320}$ These goals are best served by hiring the best research associates, graduate students, and postdocs; having access to the latest equipment and other laboratory facilities, as well as the most current data and biologic materials, such as cell lines; being the first to publish innovative and impactful research findings; and having the opportunity to interact with and present their findings to leaders in their field. Given that the university owns or at least controls the IP rights to university inventions in most Member States, an academic researcher will be less inclined to collaborate with industry unless there is an incentive (or at least no disincentive) to do so. Because an academic researcher's utility decreases if the cost of participating in a PPPP or another collaborative arrangement is not offset by the benefits, publicprivate partnerships and other academic-commercial collaborative arrangements require "specialised managers in charge of the operational management" as well as administrative procedures that "facilitate contracts" and "optimize intellectual property rights, balancing [not only] industry (patenting) and scientific interest (publishing),"321 but also, in the case of the EU, the public and economic interests of the Member State in which the university and its researchers are located and those of the European Union as a whole. In addition, university technology transfer offices should be as easy to navigate and user-friendly as possible so that academic researchers do not have to waste valuable research time coming to terms with them.

320. See Buenstorf \& Geissler, supra note 16, at 487 (noting that "continued involvement in the development of disclosed and licensed inventions comes with opportunity costs for the academic inventor").

321. Demotes-Mainard et al., supra note 305, at 329. 
The textbook game illustrated below, called the "Odd Couple,"322 shows how two parties with different utility and investment profiles will settle an argument about who should devote more resources to a given task. $^{323}$

\section{$A=6$ hours \\ A $=9$ hours}

B $=\mathbf{3}$ hours

B $=6$ hours

$-4,-1$

$4,-1$

1,2

$1,-1$

Persons A and B live in the same apartment, but they place different value on having a clean place to live. ${ }^{324}$ The game assumes that it takes twelve hours to clean the apartment per week and that each player could spend three, six, or nine hours on weekly cleaning. ${ }^{325}$ As seen in the table, if Person A derives the greatest utility from a clean apartment, then $(1,2)$ is the equilibrium and solution of the game - that is, Person A will spend nine hours cleaning and Person B will spend three. The dominant strategy for two players with different utility functions is, thus, for the party with the highest utility to invest more, even when a disproportionate share of the benefits accrues to the other party.

In this article, we assume that the pharmaceutical company (or the EU or the Member State) will act similarly to Person A because its payoff from commercialization is larger than that of the university researcher (Person B). In many of the Member States, the employer owns any invention made in the course of the employee's normal duties, and the employee is only compensated in exceptional circumstances. Yet, the savvy commercial partner realizes that it needs the active involvement of the academic researcher to commercialize most inventions. Similarly, it is important for policy makers at both the Member State and the EU level to appreciate the fact that neither the current applicable law nor the IMI contracting process ensures that academic researchers are adequately compensated financially and academically. As noted earlier, it is optimal to give the IP rights to the academic researcher "when it is more important to encourage the unit's effort to discover than to boost the customer's financial (and nonfinancial) investment in the research."326

Thus, for example, the University of Copenhagen's strategy of "focus[ing] more on the transfer of knowledge and less on financial return

322. DUTTA, supra note 302, at 52-53.

323. Id.

324. Id.

325. Id.

326. Aghion \& Tirole, supra note 318 , at 1186. 
[to the university]"327 is problematic if the government of Denmark wants to grow Denmark's translational medicine capabilities. Because the University of Copenhagen's researchers receive neither financial compensation nor non-financial incentives, such as greater prestige or access to better students, they will be less likely to participate efficiently in commercialization. If, however, policymakers in Denmark conclude that it is more important for its universities to create common goods in furtherance of open access than to commercialize inventions, the University's strategy is sensible.

In contrast with the University of Copenhagen, a number of universities promote commercialization by giving incentives to researchers who develop patentable inventions. For example, Humboldt University provides "optimised patent protection" and "equal treatment of all University members." 328 The Sorbonne "encourages faculty and students to create spin-off companies and has recently established a complete range of independent structures to facilitate its technology transfer activities." ${ }^{, 329}$ Finally, Oxford University ensures significant personal benefits to researchers by identifying, protecting, and marketing technologies through licensing, spin-out company formation, consulting, and material sales, thereby promoting the creation of economically efficient PPPPs. ${ }^{330}$

In addition, certain universities promote closer academic-industrial partnerships and spin-offs by giving tenured professors some period of time-up to two years - during which they can work full-time on a commercialization project without losing the right to return to their tenured academic position. This both enhances the researcher's opportunity to share in the financial success of the venture and reduces his or her opportunity cost if the venture fails.

B. Navigating the "Anticommons"

An "anticommons"331 exists whenever "property rights cannot be aggregated efficiently to create, for example, effective methods for assembling and screening new molecules or to realize the ambitions of

327. UNIV. OF COPENHAGEN, supra note 227, at 3.

328. Knowledge and Technology Transfer, supra note 223.

329. Pierre \& MARIE CURIE UnIV., supra note 221, at 18.

330. Research Policies, supra note 209.

331. Michael A. Heller \& Rebecca S. Eisenberg, Can Patents Deter Innovation? The Anticommons in Biomedical Research, 280 SCIENCE 698, 699 (1988). 
personalized medicine, which would require whole-genome sequencing." 332 The anticommons is particularly problematic because it affects the public availability of research tools and upstream research related to emerging areas, such as pharmacogenomics ${ }^{333}$ and microbiotics. As Heller and Eisenberg explain: "Each upstream patent allows its owner to set up another tollbooth on the road to product development, adding to the cost and slowing the pace of . . . innovation.",334

Certain empirical studies suggest that patents have not been as much of an impediment to upstream academic research as originally theorized, but this appears due in large part to the fact that "scientists typically ignore patents, and that for the most part, they get away with it." ${ }^{335}$ For example, respondents in a study of twenty-five German institutions, including large pharmaceutical firms, small- and medium-sized biotechnology firms, biotechnology research institutions, and clinical institutions associated with universities doing R\&D in genetic engineering, "indicated that patents on research tools were infringed 'behind locked laboratory doors,' that patentees were generally unaware of such infringements, and that scientists might not be aware of the legal implications of making or using patented research tools." 336 Manufacturers of generic drugs in the United States do not have that option because the Drug Price Competition and Patent Term Restoration Act of 1984 (commonly referred to as the Hatch-Waxman Act $)^{337}$ requires them to certify to the Food and Drug Administration that the generic product does not violate any valid patent. ${ }^{338}$

David C. Hoffman articulated a three-prong strategy for dealing with the anticommons created by "patent thickets" 339 and "patent stacking" in

332. Reichman \& Dreyfuss, supra note 103, at 110. For suggested alternatives, see, e.g., Hoffman, supra note 107, at 999 (recommending the creation of a broad experimental use exemption for patented biotechnology research tools).

333. Koch, supra note 22, at 264.

334. Heller \& Eisenberg, supra note 331, at 699.

335. Rebecca S. Eisenberg, Noncompliance, Nonenforcement, Nonproblem? Rethinking the Anticommons in Biomedical Research, 45 Hous. L. REV. 1059, 1080 (2008).

336. Id. at $1064-65$.

337. Pub. L. No. 98-417, 98 Stat. 1585 (1984) (codified as amended in scattered sections of 15 U.S.C., 21 U.S.C. and 35 U.S.C.).

338. 21 U.S.C. $§ 355(b),(c),(j)$.

339. A patent thicket has been described as "the overlapping set of patent rights requiring that those seeking to commercialize the technology obtain licenses from multiple patentees." Amy Kapczynski et al., Addressing Global Health Inequities: An Open Licensing Approach for University Innovations, 20 BERKELEY TECH. L.J. 1031, 1053 n.93 (2005) (quoting Carl Shapiro, Navigating the Patent Thicket: Cross-Licenses, Patent Pools, and Standard Setting, in INNOVATION PoliCY AND THE ECONOMY, Volume 1, 119, 119 (Adam B. Jaffe et al. eds., 2000)). 
the biotechnology space. ${ }^{340}$ First, create a broad experimental use exemption for public sector researchers. ${ }^{341}$ Second, establish a compulsory licensing regime for certain materials and tools. Third, limit the scope of biotechnological patents by requiring a more complete "enabling description" of the claimed invention. We encourage regulators in both the EU and the United States to consider these recommendations along with several other variations on the current Bayh-Dole regime.

\section{Create a Broad Experimental Use Exemption}

The broad experimental use exemption for public sector researchers Hoffman calls for "would cover noncommercial use of any biological material, reagent, or research tool for which an equivalent substitute is not readily available." 342 Such an exemption would legitimize what already happens behind many laboratory doors, ${ }^{343}$ giving researchers an aboveboard method for securing the rights they need for basic research, and, thereby, eliminating the current perceived need to cheat.

2. Establish a Compulsory Licensing Regime and Provide a Safe Harbor for Patent Pools

We recommend that universities in the EU continue to be precluded from granting exclusive licenses for upstream inventions and research tools funded by the government. This avoids the Harvard oncomouse situation, described in Part V. If a university patents government-funded upstream inventions and research tools, it should be required either to grant nonexclusive licenses or to create a collaborative regime, managed by a trusted intermediary, that is open to all at a commercially reasonable rate.

As a possible model for broadly applicable technologies, Hoffman cites the terms under which Stanford University and the University of California licensed the foundational Cohen-Boyer patents on basic recombinant DNA technology, the most lucrative inventions ever created in university laboratories. ${ }^{344}$ These universities widely and nonexclusively licensed the technology to public sector researchers, required institutional users to pay "a nominal annual fee for a license covering every researcher at a particular campus or research facility," and then assessed reach-

340. Hoffman, supra note 107, at 1036.

341. Id. at $1036-37$.

342. Id. at 1036-37. Similarly, Jennifer Vogel proposed a statutory research exemption for noncommercial research utilizing patented genes. Jennifer Vogel, Comment, Patenting DNA: Balancing the Need to Incentivize Innovation in Biotechnology with the Need to Make High-Quality Genetic Testing Accessible to Patients, 61 U. KAN. L. REV. 257, 292 (2012).

343. Heller \& Eisenberg, supra note 331, at 1064-65.

344. Hoffman, supra note 107, at 1040-41. 
through royalties (which were modest), but only for products that came to market. $^{345}$

In addition, as Hoffman suggests, the government could create a collective rights organization (CRO) to license "essential reagents and research tools" invented in government- or publicly-funded university laboratories. Hoffman proposed a U.S. CRO comprised of representatives from the NIH, the National Science Foundation, the Biotechnology Industry Organization, and public academic research institutions. ${ }^{346}$ Meanwhile, representatives of analogous organizations in the EU could comprise a comparable CRO there.

Patent pools "allow innovators to share value and cost to encourage free exchange of information and set technology standards" and are often used in the semiconductor, aerospace, and entertainment industries. ${ }^{347}$ They can promote the sharing of scientific information and the commercialization of academic discoveries as long as there is proper regard for preserving competition in innovation markets. ${ }^{348}$ As the European Commission noted, "collaborative IPR [intellectual property right] arrangements (cross-licensing, patent pools, etc.) generally have a positive impact, [but] they also need to be examined to ensure they are not used anti-competitively." 349

These concerns are ameliorated when the pool grants a license to all participants on a non-discriminatory, nonexclusive basis at a commercially reasonable royalty rate. ${ }^{350}$ In contrast, a patent pool limited to particular firms that compete at the same level of distribution would be an

345. Id. at 1040 .

346. Id. at 1039-40.

347. Moses III et al., supra note 50, at 187 (citing Josh Lerner \& Jean Tirole, Intellectual Property, A Better Route to Tech Standards, 343 SCIENCE 972, 972-73 (2014)). "Many [patent] pools simply divide royalties in proportion to the number of patents that each firm has contributed to the pool"; this can result in patents that were "initially different in their importance [being] made equally essential by standardization" thereby "over-reward[ing] minor innovations at the expense of major ones." Aghion \& Tirole, supra note 312 , at 972 . The use of a trusted third-party intermediary to allocate royalties can help avoid such an outcome.

348. DeP'T OF JUSTiCE \& FED. TRADE COMM'N, ANTITRUST GUIDELINES FOR COllaborations AMONG COMPETITORS § 3.32(c) (2000). "An innovation market consists of the research and development directed to particular new or improved goods or processes and the close substitutes for that research and development." Id.

349. Europe 2020 Flagship Initiative, supra note 12, at 19.

350. See generally David B. Resnik, A Biotechnology Patent Pool: An Idea Whose Time Has Come?, 3 J. PHIL., SCI. \& L. 1 (2003). As Rai et al. explain, "In recent years, the pooling of patents around information technology standards has become quite common." Rai et al., supra note 62, at 26 n.97 (citing Carl Shapiro, Navigating the Patent Thicket: Cross-Licenses, Patent Pools, and Standard Setting, in InNOvation Policy And the ECONOMY, Volume 1, 119, 119 (Adam B. Jaffe et al. eds., 2000)). 
unreasonable restraint on trade under U.S. antitrust law $^{351}$ and an abuse of dominant position under EU competition law. ${ }^{352}$ As Arti Rai and her coauthors have noted:

In practice, the overriding focus in most [U.S.] cases is . . whether the collaboration is likely to accelerate or slow the pace at which $R \& D$ efforts are pursued. The agencies specifically re-cognize that "[t]hrough the combination of complementary assets, technology, or know-how, an R\&D collaboration may enable participants more quickly or more efficiently to research and develop new or improved goods.",353

Given the uncertainty under even the more lenient U.S. antitrust standards, we agree with Professor Rai and her colleagues that any horizontal collaboration should be first vetted by the relevant antitrust/competition law authorities. By providing at least some guidance in advance, regulators in both the EU and the United States could reduce transaction costs, thereby facilitating the creation of patent pools that contribute to innovation without unduly hampering competition.

A possible model is the Predictive Safety Testing Consortium (PSTC), managed by Critical Path, a trusted non-profit intermediary created by the FDA and major pharmaceutical firms. PSTC facilitates multi-firm collaboration on methods to predict and test drug safety. ${ }^{354}$ Critical Path

collects membership fees from pharmaceutical firm participants, coordinates the selection of research projects, and (with the assistance of an advisory committee composed of Critical Path and pharmaceutical firm representatives) manages the flow of any confidential information. If the PSTC advisory committee deems it appropriate to seek patents on technology generated by the consortium, Critical Path will own the patent rights. 355

The objective of PSTC is "broad public dissemination of the results of the research and development projects" undertaken by the Consortium.

351. See, e.g., Hartford-Empire Co. v. United States, 323 U.S. 386 (1945).

352. See Commission Notice 11/01, Guidelines on the Applicability of Article 101 of the Treaty on the Functioning of the European Union to Horizontal Co-Operation Agreements, 2011 O.J. (C 11). See generally John T. Lang, Eight Important Questions on Standards Under European Competition Law, 7 Competition L. InT'L 32 (2011); Steven C. Carlson, Patent Pools and the Antitrust Dilemma, 16 Yale J. REG. 359 (1999).

353. Rai et al., supra note 62, at 35 (quoting DEP'T OF JUSTICE \& FED. TRADE COMM'N, ANTITRUST GUIDELINES FOR COLLABORATIONS AMONG COMPETITORS $§ 3.31$ (a) (2000)).

354. Id. at 17.

355. Id. 
Accordingly, "Critical Path is obligated to license any patents it may own to all comers on commercially reasonable terms.",356

Another possible model is the Biomarkers Consortium, which promotes multi-firm research on biomarkers of drug efficacy and safety. ${ }^{357}$ Unlike Critical Path, the Biomarkers Consortium does not itself retain any intellectual property rights; instead, ownership is defined by the policies followed by the inventor's employer. ${ }^{358}$ However, all participants in the Consortium that have an ownership interest in the new data and inventions arising out of a Consortium project must grant a "non-exclusive, remuneration-free license" to all of the other participants. ${ }^{359}$ Although this model may appeal to for-profit firms, it poses greater competition risks.

\section{Require More Complete Enabling Descriptions}

The EU already gives less exclusive patent protection for biotechnology inventions than the United States, thereby avoiding some of the anticommons problems inherent in the U.S. regime. ${ }^{360}$ For example, the European Directive on Biotechnology, ${ }^{361}$ which all of the Member States implemented by $2006,{ }^{362}$ treats DNA patents "as information products, whose eligibility tests should turn on the quality and industrial applicability of the information revealed." ${ }^{363}$ As a result, the European Patent Office requires DNA patent applications to set forth the "industrial applicability of the information revealed." ${ }^{364}$ We agree with Hoffman that the United States should also require biotechnology inventors to set forth in the "enablement

356. Id.

357. Id. at 18 .

358. Id.

359. Id. at 18-19 (quoting Found. FOR THE NAT'L INST. OF HEALTH, ThE Biomarkers Consortium: General Intellectual Property and Data Sharing Principles 5 (2006), http:// biomarkersconsortium.org/pdf/IP_Policies.pdf).

360. Hoffman, supra note 107 , at 1030.

361. Council Directive 98/44 of the European Parliament and of the Council of 6 July 1998 on the Legal Protection of Biotechnological Inventions, 1998 O.J. (L 213) 13. See generally Rob J. Aerts, The Industrial Applicability and Utility Requirements for the Patenting of Genomic Inventions, A Comparison between European and US Law, 26 Eur. INTELL. Prop. ReV. 349 (2004).

362. See European Comm'n, State of Play of the Implementation of Directive 98/44/EC (2007), http://ec.europa.eu/internal_market/indprop/docs/invent/state-of-play_en.pdf.

363. Reichman \& Dreyfuss, supra note 103, at 117; see also id. at $99 \mathrm{n} .64$ (citing the Convention on the Grant of European Patents arts. 52-53, 57, Oct. 5, 1973, 1065 U.N.T.S. 255 (requiring that an invention have an "industrial application," i.e., the ability to be used in any kind of industry, to be patent eligible)).

364. Reichman \& Dreyfuss, supra note 103, at 117. 
description" in the specification for the claimed invention an "inventive concept or principle whose precise contours are defined by the claims." 365

\section{Promote Open Innovation Collaborations}

Certain public-private projects, especially those involving the collection of large digital data sets (so-called Big Data), are particularly well-suited to open innovation arrangements. For example, the SNP Consortium is a non-profit foundation established by the Wellcome Trust, pharmaceutical and biotechnology firms, and academic research centers with the objective of publishing "a high-density SNP map of the human genome." ${ }^{366}$ The Consortium has amassed a database of more than 3.1 million SNPs. ${ }^{367}$ A SNP, pronounced "snip," is a single nucleotide polymorphism, that is, "a difference in a single DNA building block, called a nucleotide." 368 SNPs "are the most common type of genetic variation among people. ... For example, a SNP may replace the nucleotide cytosine (C) with the nucleotide thymine (T) in a certain stretch of DNA.... [T] here are roughly 10 million SNPs in the human genome." ${ }^{369}$ As the NIH explained, SNPs "may help predict an individual's response to certain drugs, susceptibility to environmental factors such as toxins, and risk of developing particular diseases." 370

Merck \& Co. and Washington University have created the Merck Gene Index, "a public database of gene sequences corresponding to human genes" designed "to preserve open access to knowledge that could aid in drug discovery." "371 Ironically, had this research been funded with federal money, then Washington University could not have put the invention in the public domain - thereby precluding anyone from patenting it - because title to the inventions would have reverted to the U.S. government.

365. Hoffman, supra note 107, at 1041-42 (quoting Robert P. Merges \& Richard R. Nelson, On the Complex Economics of Patent Scope, 90 COLUM. L. REV. 839, 846 (1990)).

366. Koch, supra note 22, at 279 (quoting Celia M. Henry, Pharmacogenomics, CHEMICAL \& ENGINEERING NEWS, Aug. 13, 2001, at 37, 39).

367. Id.

368. What Are Single Nucleotide Polymorphisms (SNPs)?, GENETICS HOME REFERENCE (Nov. 23, 2015), http://ghr.nlm.nih.gov/handbook/genomicresearch/snp.

369. Id.

370. Id.

371. Vertinsky, supra note 296, at 1991. The Merck Gene Index has been described "as an example of efforts to preempt patent rights and protect the public domain for inputs into drug discovery and development." Id. at 1991 n.168 (citing Robert P. Merges, A New Dynamism in the Public Domain, 71 U. CHI. L. REV. 183, 188-89 (2004)). 


\section{Other Recommended Changes to the Bayh-Dole Regime}

We submit that the current Bayh-Dole regime, which forces a university to patent an invention or lose its rights, is ill-suited to the development - in both the United States and the EU- of biomedical drugs tailored to individual genomes and other types of translational medicine. At least for upstream inventions and research tools, we argue that universities should have the option of promptly publishing these inventions, thereby precluding anyone from obtaining a patent on them. ${ }^{372}$ IBM and other software and hardware firms have for a number of years put certain inventions in the public domain in this fashion. ${ }^{373}$ In addition, Red Hat and other "open source" software companies ${ }^{374}$ have created outlets for publishing prior art, which helps prevent the erroneous patenting of existing technology and the creation of "patent thickets" that unduly inhibit future discoveries.

We also support the European analogue to the recommendation that Congress amend Bayh-Dole to give the NIH, instead of the Commerce Department, the power to dictate, as part of the grant application process itself, the grantee's right to patent the funded work and to exclusively license it. ${ }^{375}$ This would not, of course, preclude a private firm from funding a line of research with high economic potential, so there would be a market check on the funding agency's conditions. Thus, to the extent that biotech firms and large pharmaceutical firms develop pharmacogenetic test kits and other innovations without using government-funded research, they would be able to patent those inventions without a duty to grant licenses to other private firms.

372. Vertinsky, supra note 296, at 2002 (recommending that "[t $\mathrm{t}$ he university's right to elect title should instead be based on a requirement to engage in reasonable efforts to support the public utilization of the invention, with patenting considered as one alternative strategy").

373. Fully Tested Public Domain Software Now Available for IBM, 6 INFO. ToDAY 48, 48 (May 1989) (noting that public domain software is available for IBM and Apple computers).

374. As Kapczynski and her coauthors noted, "The emergence of free and open source software development has led to increased interest in defining the conditions for sustainable and successful nonproprietary production strategies - for software and more generally for networked information production and some classes of physical resources. These approaches... frequently rely upon innovative contractual provisions to create a self-perpetuating commons." Kapczynski et al., supra note 339, at 1040. With regard to open source copyright licensing, see generally Robert W. Gomulkiewicz, Enforcement of Open Source Software Licenses: The MDY Trio's Inconvenient Complications, 14 Yale J. L. \& Tech. 106, 111-16 (2011); Dennis M. Kennedy, A Primer on Open Source Licensing Legal Issues: Copyright, Copyleft and Copyfuture, 20 ST. LouIS U. PUB. L. REV. 345 (2001).

375. Arti K. Rai \& Rebecca S. Eisenberg, Bayh-Dole Reform and the Progress of Biomedicine, 66 L. \& CONTEMP. PRoBS. 289, 291, 313-14 (2003) (recommending that the NIH and other government agencies be given greater authority to limit the patenting of certain publicly funded research). 
Given the devastating effect of budget cuts on basic research funding in the United States ${ }^{376}$ and the EU, ${ }^{377}$ it may be appropriate to give the NIH in the United States, and an analogous institution in the EU, the right to receive a small percentage of the royalties generated by government-funded inventions or, in the EU, government- or IMI-funded inventions, that are ultimately commercialized. This is tricky, however, because it is important not to to unduly restrict funding for the type of research the private markets are most unlikely to fund: basic research. Thus, the government should limit the percentage of publicly-funded grants eligible for royalty recovery.

\section{Complying with the EU State Aid Restrictions}

Another possible impediment to commercializing government-funded inventions in the EU is uncertainty regarding the application to PPPPs of the restriction in Article 107(1) of the Treaty on the Functioning of the European Union ("TFEU") on the use of State aid to favor a particular private enterprise. Article 107(1) provides:

Save as otherwise provided in the Treaties, any aid granted by a Member State or through State resources in any form whatsoever which distorts

376. "Spending on basic research has fallen" with the director of the NIH, Dr. Francis S. Collins, calling "2013 one of his agency's darkest years" and characterizing the cutbacks as "profoundly discouraging." William J. Broad, Billionaires with Big Ideas Are Privatizing American Science, N.Y. TIMES, Mar. 15, 2014, at A1, http://www.nytimes.com/2014/03/16/science/billionaires-with-big-ideasare-privatizing-american-science.html? $\mathrm{r}=1$. One concern with reduced federal funding (and the current trend of increased private funding) is that the "social contract that cultivates science for the common good" is at risk, as the philanthropic funds "tend to enrich elite universities at the expense of poor ones, while undermining political support for federally sponsored research and its efforts to foster a greater diversity of opportunity... among the nation's scientific investigators." Id. Another concern is that privately funded research tends to focus on illnesses that "predominantly afflict white people," thus expanding the unequal gap that exists in disease research along economic and racial lines. Id. The effect of private funds on American research has not been quantified, but the National Science Foundation "recently announced plans to begin surveying the philanthropic landscape." Id.

377. See Editorial, Science Funding: Championing Research in Tough Times, 14 NATURE CELL Biology 439, 439 (May 2012), http://www.nature.com/ncb/journal/v14/n5/pdf/ncb2499.pdf ("[S]ubstantial cuts in fiscal spending" have been "triggered by the global economic crisis, highlight[ing] a pressing need to safeguard funding to ensure the future health of the scientific research enterprise." The article stated that science spending had been "frozen" in the U.K., with "government R\&D expenditure failing to match that of other developed countries," and that reduced endowments to certain UK research centers had resulted in cuts to basic research funding. The Horizon 2020 venture and its focus on research was referred to as a "step[] in the right direction."). Cuts have also been made to science budgets at European universities. "Since 2009, Italy has seen the recruitment of scientists fall by $90 \%$ and the amount spent on basic research drop to nothing," and in Spain, the amount spent on "civilian research and development has dropped by $40 \%$ " with less than $10 \%$ of researchers who retire being replaced. Karen MacGregor, Scientists Protest Cuts, Study Shows HE [Higher Education] Funding Divide, UNIV. WORLD NEWS (Oct. 11, 2014), http://www.universityworldnews.com/ article.php?story $=20141010105248818$. 
or threatens to distort competition by favouring certain undertakings or the production of certain goods shall, in so far as it affects trade between Member States, be incompatible with the internal market. ${ }^{378}$

Thus, State aid that distorts or threatens to distort competition is prohibited insofar as it affects trade between Member States.

State aid control is an integral part of EU competition policy and a necessary safeguard that preserves effective competition and free trade in the single market. Absent this control, Member States could use State aid strategically to promote national economic interests without regard for spillover effects on other Member States or adverse effects on the internal market and the common EU interest. ${ }^{379}$

Neither TFEU Articles 107 and 108 nor EU law in general set forth uniform rules that can be applied to ensure the correct separation of economic and non-economic activities for State aid purposes. Instead, this responsibility rests with the Member States, supported by the European Commission. $^{380}$

In principle, all public funding to universities is State aid. As a result, universities in the EU must comply with the State aid rules when they collaborate for economic gain with industry. ${ }^{381}$ That is why, historically, many universities clearly separated their economic and non-economic activities. Fortunately, recent changes in EU policy have made it easier to commercialize government-funded research without violating the State aid restrictions. ${ }^{382}$

State aid that contributes to well-defined objectives of common European interest without unduly distorting competition or affecting trade between Member States may be compatible with the common market under

378. Consolidated Version of the Treaty on the Functioning of the European Union art. 107(1), Mar. 30, 2010, 2010 O.J. (C 83) 91 [hereinafter Treaty on the Functioning of the EU].

379. Org. for Econ. Co-operation \& Devel., Directorate for Fin. \& Enter. Affairs Competition Comm., Global Forum on Competition, Competition, State Aid and Subsidies: Contribution from the European Union, 2, DAF/COMP/GF/WD(2010)3 (Jan. 11, 2010).

380. The EU Commission can declare the university's contribution to be compatible with the internal market. In such cases, the agreement must be notified to the Commission prior to commencement.

381. See Bernhard von Wendland, State Aid and Public Funding for Universities and Other Research Organisations, COMPETITION POL'Y NEWSL., no. 2, 2010, at 54, 54-55.

382. European Commission Press Release IP/14/586, State Aid: Commission Adopts New Rules Facilitating Public Support for Research, Development and Innovation (May 21, 2014), http://europa.eu/ rapid/press-release_IP-14-586_en.htm. The new rules, effective on July 1, 2014, are designed to ensure that public funds are used as needed and that "state aid mobilises private investments in projects that would otherwise not be implemented, while preserving competition in the Single Market," and to "facilitate the transition of knowledge and ideas to the market." Id. at 1. 
TFEU Article 107(3). For example, the EU adopted orphan drug legislation in $2000^{383}$ that was patterned on the U.S. Orphan Drug Act ("ODA") enacted in $1983 .{ }^{384}$ According to Article 1 of Regulation (EC) 141/2000 on Orphan Medicinal Products, the purpose of the regulation is laying down an EU procedure for designating certain medicinal products as "orphan products" and increasing incentives to research, develop, and market them.

The ODA provides incentives for private firms to develop (1) drugs for diseases affecting fewer than 200,000 persons in the United States and (2) drugs for diseases affecting a larger population in the United States for which "there is no reasonable expectation that the cost of developing and making available in the United States a drug for such disease or condition will be recovered from sales in the United States of such drug." ${ }^{385}$ The ODA provides a seven-year period of marketing exclusivity for the drug, even if it would not otherwise be eligible for patenting, ${ }^{386}$ federal funding through the Food and Drug Administration, ${ }^{387}$ and a $50 \%$ tax credit for qualified expenses for human clinical trials. ${ }^{388}$

The EC orphan drug legislation is similar. In the EU, orphan medicinal products are defined as those intended for the "diagnosis, prevention or treatment of a life-threatening or chronically debilitating" condition that affects no more than 5 in 10,000 people in the European Union. ${ }^{389}$ The European Commission has authorized 106 orphan medicines and designated 1,058 products as orphan medical products. ${ }^{390}$ The sponsors responsible for these medicines benefit from incentives including fee waivers for the regulatory procedures or ten-year market exclusivity. ${ }^{391}$ The period of exclusivity "may be curtailed by four years if a product is

383. Regulation 141/2000, of the European Parliament and of the Council of 16 December 1999 on Orphan Medicinal Products, 2000 O.J. (L 18) 1.

384. Orphan Drug Act of 1983, Pub. L. No. 97-414, 96 Stat. 2049 (codified as amended in scattered sections of $15,21,26,35$, and 42 U.S.C.). An orphan drug is used to treat a rare disease or condition. 21 U.S.C. $\$ 360 a a(a)(2012)$.

385. 21 U.S.C. $\$ 360 b b(a)(2)(2012)$.

386. 21 U.S.C. $\S 360 \mathrm{cc}(\mathrm{a})(2)(2012)$.

387. 21 U.S.C. $\$ 360$ ee (2012).

388. 26 U.S.C. $\S 45 C(a)(2012)$.

389. Sci. Secretariat of the European Union Com. of EXPERTS on Rare Diseases (EUCERD) JOINT ACTION, 2014 REPORT ON THE STATE OF THE ART OF RARE DisEASE ACTIVITIES IN Europe - PART I: OVERVIEW of RARE Disease ACtivities In EuROPE 9 (2014) [hereinafter RARE DiSEASE ACTIVITIES IN EUROPE].

390. John F. Ryan, Turning the Challenge of Rare Diseases into an Opportunity for Europe, PARLIAMENT MAG. (Nov. 4, 2014), https://www.theparliamentmagazine.eu/articles/opinion/turningchallenge-rare-diseases-opportunity-europe.

391. RARE DISEASE ACTIVITIES IN EUROPE, supra note 389, at 9. 
'sufficiently profitable.",392 In 2003, the British Nuffield Council on Bioethics recommended that regulators "use existing orphan medicine legislation, or any other policy instrument with equivalent effect, to provide incentives for development" of pharmacogenetics products. ${ }^{393} \mathrm{We}$ agree with this recommendation and, as argued below, consider it consistent with the EU State aid rules.

TFEU Article 179(1) identifies research and development and innovation ("R\&D\&I") as an important EU objective:

The Union shall have the objective of strengthening its scientific and technological bases by achieving a European research area in which researchers, scientific knowledge and technology circulate freely, and encouraging it to become more competitive, including in its industry, while promoting all the research activities deemed necessary by virtue of other Chapters of the Treaties. ${ }^{394}$

Article 180 provides:

[t]he Union shall carry out the following activities, complementing the activities carried out in the Member States:

(a) implementation of research, technological development and demonstration programmes, by promoting cooperation with and between undertakings, research centres and universities;

(b) promotion of cooperation in the field of Union research, technological development and demonstration with third countries and international organisations;

(c) dissemination and optimisation of the results of activities in Union research, technological development and demonstration;

(d) stimulation of the training and mobility of researchers in the Union. $^{395}$

Both the Europe 2020 strategy 396 and the "Innovation Union" flagship initiative acknowledge that State aid can "actively and positively contribute ... by prompting and supporting initiatives for more innovative,

392. Dan Phair, Orphan Drug Programs, Public-Private Partnerships and Current Efforts to Develop Treatments for Diseases of Poverty, 4 J. HEALTH \& BiOMEDICAL L. 193, 207 (2008).

393. Nuffield Council on Bioethics, Pharmacogenetics: ETHICAl Issues, Summary and RECOMMENDATIONS xix (2003), http://nuffieldbioethics.org/wp-content/uploads/2014/07/Pharma cogenetics-Summary-and-recommendations.pdf.

394. Treaty on the Functioning of the EU, supra note 378, art. 179(1), 2010 O.J. (C 83) at 128.

395. Id. art. 180, 2010 O.J. (C 83) at 129.

396. Communication from the Commission, Europe 2020: A Strategy for Smart, Sustainable and Inclusive Growth, COM (2010) 2020 final (Mar. 3, 2010) [hereinafter Europe 2020]. 
efficient and greener technologies, while facilitating access to public support for investment, risk capital and funding for research and development." ${ }^{397}$ Collaboration between universities and the pharmaceutical industry through PPPPs can stimulate innovation, spur growth, and enhance value by decreasing the general innovation gap in the pharmaceutical industry and increasing the competitiveness of EU commercial firms. But the contract must pass muster under the State aid balancing test, where "the Commission balances the negative effects on trade and competition in the common market with its positive effects in terms of contributing to the achievement of well-defined objectives of common interest." ${ }^{398}$ The balancing test examines the following elements:

(1) Is the aid measure aimed at a well-defined objective of common interest (e.g., growth, employment, cohesion, environment)?

(2) Is the aid well designed to deliver the objective of common interest, i.e., does the proposed aid address the market failure or other objective?

(i) Is State aid an appropriate policy instrument?

(ii) Is there an incentive effect, i.e., does the aid change the behaviors of firms?

(iii) Is the aid measure proportional, i.e., could the same change in behavior be obtained with less aid?

(3) Are the distortions of competition and effect on trade limited, so that the overall balance is positive? ${ }^{399}$

\section{In 2012, the European Commission launched}

State Aid Modernisation (SAM), an ambitious reform package of State Aid policy with three key objectives: to foster growth in a strengthened, dynamic and competitive internal market, in line with the objectives of the Europe 2020 growth strategy; to focus enforcement on cases with the

397. Communication from the Commission to the European Parliament, the Council, the European Economic and Social Committee and the Committee of the Regions, EU State Aid Modernisation (SAM), ๆ 10, COM (2012) 209 final (Aug. 5, 2012) (citing Europe 2020, supra note 396, at 20). Before granting State aid, Member States must either (1) obtain the authorisation from the Commission (notification) or (2) ensure that the State aid is exempted by a general Commission Block Exemption Regulation, which considers the most obvious market failures and allows Member States to take State aid measures that could lead to limited market distortions. Hence, the Commission can focus on large State aid cases with high risk of competition and trade distortions. State Aid in General, EUROPEAN COMM'N, 1-2, http://ec.europa.eu/agriculture/stateaid/gl-chapters-1-and-2_en.pdf (last visited Dec. 5, 2014).

398. See Bente Tranholm-Schwarz et al., The Real Economy-Challenges for Competition Policy in Periods of Retrenchment, COMPETITION POL'Y NEWSL., no. 1, 2009, at 3, 3-4.

399. Commission Notice, Community Framework for State Aid for Research and Development and Innovation, § 1.3.1., 2006 O. J. (C 323) 1, 5. 
biggest impact on internal market; [and] to streamline rules and ensure faster decisions. 400

The revised Enabling Regulation, adopted by the Council in 2013, introduced new categories of aid that the Commission may decide to exempt from the obligation of prior notification, including innovation aid. The European Commission has identified the following R\&D\&I measures for which State aid may, under specific conditions, be compatible with the internal market:

(a) aid for R\&D projects where the aided part of the research project falls within the categories of fundamental research and applied research, of which the latter can be divided into industrial research and experimental development. ...; $;^{401}$

(b) aid for feasibility studies related to R\&D projects, which aims at overcoming a market failure primarily related to imperfect and asymmetric information; ${ }^{402}$

(c) aid for the construction and upgrade of research infrastructures, which mainly addresses the market failure stemming from coordination difficulties. . ..;.$^{403}$

(d) aid for innovation activities, which is mainly targeted at market failures related to positive externalities (knowledge spill-overs), coordination difficulties and, to a lesser extent, asymmetric information. ...; . $^{404}$

(e) aid for innovation clusters .... ${ }^{405}$

400. EC Taking Stock 2014, supra note 8, at 38 .

401. Commission Communication, Framework for State Aid for Research and Development and Innovation, I 12(a), 2014 O.J. (C 198) 1, 4 [hereinafter Commission Framework for State Aid] (emphasis omitted). "Such aid is mainly targeted at the market failure related to positive externalities (knowledge spill-overs), but may also address a market failure caused by imperfect and asymmetric information or (mainly in collaboration projects) a coordination failure[.]" Id.

402. Id. 1 12(b) (emphasis omitted).

403. Id. I 12(c) (emphasis omitted). "High-quality research infrastructures are increasingly necessary for ground-breaking research, as they attract global talent and are essential for example for information and communication technologies and key enabling technologies[.]" Id. For definitions of key enabling technologies, see Communication From the Commission to the European Parliament, the Council, the European Economic and Social Committee and the Committee of the Regions, A European Strategy for Key Enabling Technologies - A Bridge to Growth and Jobs, COM (2012) 341 final (June 26, 2012).

404. Commission Framework for State Aid, supra note 401, ๆ 12(d) (emphasis omitted).

405. Id. I 12(e) (emphasis omitted). Coordination problems can hamper the development of clusters, or limit the interactions and knowledge flows within and between clusters. State aid could help address this market failure, first by supporting the investment in open and shared infrastructures for innovation clusters and, second, by supporting, for no longer than ten years, the operation of clusters for the enhancement of collaboration, networking, and learning. Id. 
If, however, a PPPP agreement is not on market terms-e.g., if the university does not demand the market price for its share of intellectual property rights transferred to the for-profit firm as a result of the collaboration - then the university's entire contribution to the project might be considered State aid. ${ }^{406}$

Thus, an exemption to the State aid restrictions is available, pursuant to TFEU Articles 107(3)(b) and 107(3)(c), ${ }^{407}$ for pharmaceutical R\&D performed by a partnership between a university and a private enterprise as long as the arrangement, including the royalties and licensing fees payable, is on market terms. Hence, both to reduce transaction costs ${ }^{408}$ and to provide more certainty with respect to the EU competition laws and the State aid regulation, we propose that regulators in the EU create a safe harbor for PPPPs using pre-approved standardized licensing contracts, such as the Uniform Biological Materials Transfer Agreement. ${ }^{409}$ Universities $^{-}$ are often willing to acquire materials in accordance with such agreements, but they demand more favorable terms when asked to transfer their own materials, creating a collective action problem. ${ }^{410}$ By offering a safe harbor for parties willing to accept such an agreement, regulators in the EU could help facilitate the transfer of materials as well as technologies. As a logical first step, we recommend that the European Commission add a State aid

406. Id. $-28(\mathrm{~d})$ (stating that the Commission considers that "no indirect State aid is awarded to the participating undertakings" if "the research organisations [defined to include universities] ... receive compensation equivalent to the market price for the [intellectual property rights] which result from their activities and are assigned to the participating undertakings").

407. See also Communication From the Commission to the Council, the European Parliament, the European Economic and Social Committee and the Committee of the Regions, Investing in Research: An Action Plan for Europe, COM (2003) 226 final/2 (June 4, 2003); Europe 2020, supra note 396; Case 173/73, Italy v. Comm'n, 1974 E.C.R. 709; Case C-487/06 P, British Aggregates Ass'n v. Comm'n, 2008 E.C.R. I-10515.

408. See Joshua Fairfield, The Cost of Consent: Optimal Standardization in the Law of Contract, 58 EMORY L.J. 1401, 1409 (2009) ("The economic analysis of boilerplate discusses the benefits of contract standardization for contract drafters. It argues quite effectively that network effects cause contract drafters to reuse contract language (in the form of boilerplate) to save themselves drafting costs, economize on learning costs, reuse 'safe' language that has been vetted by courts, and signal to prospective counterparties that the contract drafter does not seek an unfair advantage through the drafting process."). See also Marcel Kahan \& Michael Klausner, Standardization and Innovation in Corporate Contracting (or the "Economics of Boilerplate"), 83 VA. L. REV. 713, 719-20 (1997) (defining "learning benefits" as "(a) drafting efficiency; (b) reduced uncertainty over the meaning and validity of a term due to prior judicial rulings; and (c) familiarity of a term among lawyers, other professionals, and the investment community").

409. Further information about this agreement can be accessed at Uniform Biological Materials Transfer Agreement, ASS'N OF UNIV. TECH. MANAGERS, http://www.autm.net/resources-surveys/ material-transfer-agreements/uniform-biological-material-transfer-agreement/ (last visited Dec. 5, 2014).

410. Rai \& Eisenberg, supra note 375, at 305-06. 
safe harbor to the European IMI regime, provide guidance on the contractual provisions that would come within it, and require bidders for IMI funds to include their proposed contract with their bid.

Because one size rarely fits all, ${ }^{411}$ the standardized contracts "blessed" by the EU regulators could provide alternative licensing terms from which the parties to a PPPP could select. Like Beirne Roose-Snyder and Megan Doyle, who proposed "a comprehensive approach to humanitarian licensing for universities - a Global Health Licensing Program," which includes "a toolbox of access licensing options for technology transfer offices to use during licensing negotiations," 412 we encourage the European Commission to offer various alternative arrangements. One might be a nonexclusive license of the sort offered by Stanford and the University of California when it licensed the Cohen-Boyer recombinant DNA patents. ${ }^{413}$ Patent pools open to all that allow non-participants to obtain nonexclusive licenses at a commercially reasonable rate, perhaps as determined by a trusted intermediary, are another option. At the same time, certain practices, such as mandatory reach-back licenses and prohibitions on the publication of adverse test results by academics receiving private funding, ${ }^{414}$ should be prohibited. Universities and private firms would still be permitted to negotiate customized contracts that do not violate these prohibitions, but they would not have the benefit of ex ante governmental approval.

\section{CONCLUSION}

PPPPs and other forms of public-private technology transfer are powerful tools for bringing life-saving therapies to patients. While not yet widely employed in the European pharmaceutical industry, such arrangements can both enhance competitiveness and improve societal and individual patient welfare. As a result, we argue that policymakers in the EU should encourage utilization of such arrangements and facilitate their formation and operation by clarifying the applicability of the State aid limitations.

A comparative analysis of the EU and U.S. approaches to translational medicine shows that there are lessons to be shared. PPPPs and other forms

411. Beirne Roose-Snyder \& Megan K. Doyle, The Global Health Licensing Program: A New Model for Humanitarian Licensing at the University Level, 35 AM. J. L. \& MED. 281, 284 (2009) ("No single approach will meet the needs of every negotiating partner or every type of licensed intellectual property, and there is no silver bullet to bridge the access gap.").

412. Id. at 284 .

413. Rai \& Eisenberg, supra note 375 , at 300.

414. See, e.g., Downie \& Herder, supra note 109, at 34 (offering examples of instances when private firms threatened legal action if an academic published negative results or commentary). 
of collaborative research and university technology licensing can significantly enhance research, development, and commercialization in the pharmaceutical sector and other similar industries. The EU can apply the experiences from Bayh-Dole and technology transfer in the United States, and the United States can emulate the open innovation aspects of the European IMI concept, the open access objectives embodied in Horizon 2020, and the tighter patenting standards imposed by the European Patent Office. In particular, the EU could encourage the Member States to permit universities to obtain patents on government-funded inventions, perhaps with a royalty-sharing arrangement akin to Denmark's. At the same time, the U.S. Congress should consider removing obstacles to cooperative research and commercialization by amending the Bayh-Dole Act to promote more open innovation for certain upstream research and research tools.

There is another option available to lawmakers in both the EU and the United States, in addition to "concrete legislation." Because the PPPP contract is the law of the parties, regulators could promote more efficient allocations of intellectual property rights by developing model contracts for the allocation of IP rights generated by publicly sponsored research. For example, Congress could require the inclusion of a specific clause in a PPPP contract relating to research funded by the National Institutes of Health in the United States. Similarly, the European Commission could, as a start, require a specific clause in an IMI contract and transition to offering standard contract terms for other types of PPPPs. The European Commission can also outline a safe harbor procedure to ensure that university inventions are licensed on market terms. Both the United States and the EU could at least offer templates from which grant applicants could choose. A funding agency could then take those contractual terms into account when reviewing grant applications. For basic research that depends primarily on university scientists for success, the preferred allocation might be to the scientists. For more applied research, it might be best to rely on university technology transfer offices to negotiate directly with the industry partner. 